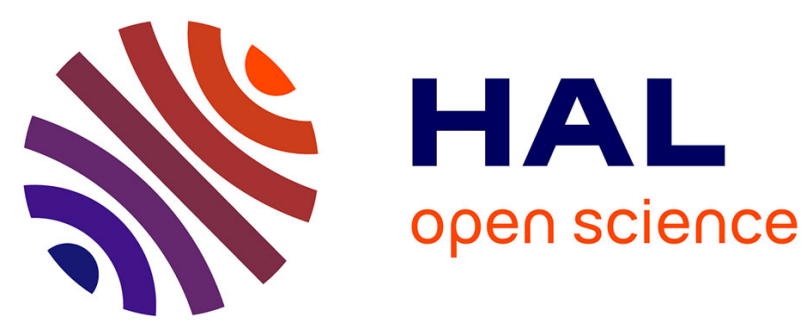

\title{
Magmatism, serpentinization and life: Insights through drilling the Atlantis Massif (IODP Expedition 357)
}

Gretchen Früh-Green, Beth Orcutt, Stéphane Rouméjon, Marvin Lilley, Yuki

Morono, Carol Cotterill, Sophie Green, Javier Escartin, Barbara John, Andrew Mccaig, et al.

\section{To cite this version:}

Gretchen Früh-Green, Beth Orcutt, Stéphane Rouméjon, Marvin Lilley, Yuki Morono, et al.. Magmatism, serpentinization and life: Insights through drilling the Atlantis Massif (IODP Expedition 357). Lithos, 2018, 323, pp.137-155. 10.1016/j.lithos.2018.09.012 . hal-02024193

\section{HAL Id: hal-02024193 \\ https://hal-amu.archives-ouvertes.fr/hal-02024193}

Submitted on 5 Dec 2020

HAL is a multi-disciplinary open access archive for the deposit and dissemination of scientific research documents, whether they are published or not. The documents may come from teaching and research institutions in France or abroad, or from public or private research centers.
L'archive ouverte pluridisciplinaire HAL, est destinée au dépôt et à la diffusion de documents scientifiques de niveau recherche, publiés ou non, émanant des établissements d'enseignement et de recherche français ou étrangers, des laboratoires publics ou privés. 


\section{UNIVERSITY OF LEEDS}

This is a repository copy of Magmatism, serpentinization and life: Insights through drilling the Atlantis Massif (IODP Expedition 357).

White Rose Research Online URL for this paper:

http://eprints.whiterose.ac.uk/139125/

Version: Accepted Version

\section{Article:}

Früh-Green, GL, Orcutt, BN, Rouméjon, S et al. (32 more authors) (2018) Magmatism, serpentinization and life: Insights through drilling the Atlantis Massif (IODP Expedition 357). Lithos, 323. pp. 137-155. ISSN 0024-4937

https://doi.org/10.1016/j.lithos.2018.09.012

(C) 2018 Elsevier B.V. All rights reserved. Licensed under the Creative Commons Attribution-Non Commercial No Derivatives 4.0 International License (https://creativecommons.org/licenses/by-nc-nd/4.0/).

\section{Reuse}

This article is distributed under the terms of the Creative Commons Attribution-NonCommercial-NoDerivs (CC BY-NC-ND) licence. This licence only allows you to download this work and share it with others as long as you credit the authors, but you can't change the article in any way or use it commercially. More information and the full terms of the licence here: https://creativecommons.org/licenses/

\section{Takedown}

If you consider content in White Rose Research Online to be in breach of UK law, please notify us by emailing eprints@whiterose.ac.uk including the URL of the record and the reason for the withdrawal request. 
Gretchen L. Früh-Green ${ }^{\mathrm{a},{ }^{*}}$, Beth N. Orcutt ${ }^{\mathrm{b}}$, Stéphane Rouméjon ${ }^{\mathrm{a}}$, Marvin D. Lilley ${ }^{\mathrm{c}}$, Yuki

${ }^{a}$ Institute of Geochemistry and Petrology, ETH Zurich, Clausiusstrasse 25, 8092 Zürich, Switzerland

${ }^{\mathrm{b}}$ Bigelow Laboratory for Ocean Sciences, East Boothbay, ME, USA

${ }^{c}$ University of Washington, School of Oceanography, Seattle WA 98195, USA

${ }^{\mathrm{d} J a p a n}$ Agency for Marine-Earth Science and Technology, Kochi Institute for Core Sample Research, Kochi, Japan

${ }^{\mathrm{e}}$ ECORD Science Operator, British Geological Survey, Edinburgh EH14 4AP, UK

${ }^{\mathrm{f}}$ Institut de Physique du Globe de Paris, CNRS, 1 rue Jussieu, 75238 Paris cedex 05, France

g University of Wyoming, Laramie WY 82071, USA

${ }^{\mathrm{h}}$ University of Leeds, School of Earth and Environment, Leeds LS2 9JT, United Kingdom

I Institute of Geological Sciences, Freie Universität Berlin, Malteserstrasse 74-100, 12249 Berlin, Germany

$\mathrm{j}$ The Australian National University, Department Research School of Earth Sciences, Mills Rd, Acton, Australia. ${ }^{1}$ Present address: CSIRO Mineral Resources, 26 Dick Perry Avenue, Kensington WA 6151, Australia

${ }^{\mathrm{k}}$ ECORD Science Operator, Department of Geology, University of Leicester,University Road, Leicester LE1 7RH, United Kingdom

${ }^{1}$ University of South Carolina, 701 Sumter St. EWS 617, Columbia SC 29208, USA 
${ }^{\mathrm{m}}$ Michigan State University, 288 Farm Lane, East Lansing MI 48824,USA

${ }^{\mathrm{n}}$ University of Utah, 257 South 1400 East, Salt Lake City, UT 84112-0840, USA

${ }^{\circ}$ Kanazawa University, Department of Earth Sciences, Kakuma Kanazawa, Ishikawa 920-1192 JAPAN. ${ }^{2}$ Present address: Atmosphere and Ocean Research Institute, The University of Tokyo 5-1-5, Kashiwanoha, Kashiwa, Chiba 277-8564 Japan

${ }^{\mathrm{p}}$ Institute of Geosciences and Earth Resources - CNR, Via Moruzzi 1, 56124 Pisa, Italy

${ }^{\mathrm{q}}$ Physics of Geological Processes, University of Oslo, Sem Sælands vei 24, 0371 Oslo, Norway

${ }^{\mathrm{r}}$ Mediterranean Institute of Oceanography (MIO), Aix Marseille Univ., Université de Toulon, CNRS, IRD, MIO UM 110, 13288, Marseille, France

${ }^{\mathrm{s}}$ Korea University, Department Earth and Environmental Sciences, Seoul 136-701, Republic of Korea. Present address: Department of Geosciences, King Fahd University of Petroleum and Minerals, Dhahran 31261, Saudi Arabia

${ }^{\mathrm{t}}$ University of Colorado - Boulder, 2200 Colorado Ave., Boulder CO 80466, USA

" University of Southampton, National Oceanography Centre, European Way, Southampton, SO14 3ZH, United Kingdom. ${ }^{4}$ Present address: School of Geography, Earth and Environmental Sciences, 109 Fitzroy Building, Plymouth University, Plymouth PL4 8AA, United Kingdom

${ }^{v}$ GEOMAR Helmholtz Centre for Ocean Research Kiel, Wischhofstr. 1-3, 24148 Kiel, Germany

${ }^{\text {w }}$ University of Hawaii at Manoa, SOEST-Hawaii Institute of Geophysics and Planetology, 1680 East West Road, Honolulu 96822, USA

${ }^{\mathrm{x}}$ GeoZentrum Nordbayern, Friedrich-Alexander-University Erlangen-Nuremberg, Schlossgarten 5a, 91054 Erlangen, Germany

${ }^{y}$ Guangzhou Institute of Geochemistry, Chinese Academy of Sciences, Key Laboratory of Marginal Sea Geology, 511 Kehua Street, Tianhe, Guangzhou 510640, China

${ }^{\mathrm{z}}$ Shimane University, Faculty of Science and Engineering, 1060 Nishikawatsu Matsue, Shimane 690-8504, Japan. ${ }^{5}$ Present address: Mineral Resources and Technology, Faculty of Science and Technology, Uva Wellassa University, Passara Road, Badulla 90000, Sri Lanka

${ }^{\text {aa }}$ University of British Columbia, Earth, Ocean and Atmospheric Sciences, 2020-2207 Main Mall, Vancouver, BC V6T-1Z4, Canada

${ }^{\mathrm{ab}}$ Centre for Geobiology, University of Bergen, Allegaten 4, 5007 Bergen, Norway 
64 *Corresponding author: Gretchen L. Früh-Green at Institute of Geochemistry and Petrology,

65 ETH Zurich, Clausiusstrasse 25, 8092 Zürich, Switzerland. Email address: frueh-

$66 \quad$ green@erdw.ethz.ch

67

68 Keywords: IODP Expedition 357, Atlantis Massif, detachment faulting, serpentinization, Si

69 metasomatism, deep biosphere 


\section{Introduction}

71 It is now well recognized that slow spreading ridges are formed by interlinked processes of

72 magmatism, asymmetric extension, and detachment faulting that result in the exposure and

73 alteration of lower crustal and mantle-derived rocks in oceanic core complexes (OCCs)

74 (Andreani et al., 2007; Boschi et al., 2006; Cannat, 1993; Früh-Green et al., 2004; Karson et al.,

75 2006; Kelemen et al., 2007; Rouméjon et al, 2015). OCCs contain olivine-rich rocks that interact

76 with seawater to produce serpentinite over a range of temperatures (Andreani et al., 2007; Boschi

77 et al., 2006a; Boschi et al., 2006b; Cannat, 1993; Früh-Green et al., 2004; Karson et al., 2006;

78 Kelemen et al., 2007; Rouméjon et al, 2015). Serpentinization is a fundamental process that

79 controls rheologic and geophysical properties (Escartin et al, 2008; Schroeder et al, 2002) and is

80 associated with the uptake or release of many major and minor components (Alt and Shanks,

81 2003; Boschi et al., 2008; Delacour et al., 2008; Früh-Green et al., 2004; Schwarzenbach et al.,

82 2012). Serpentinization reactions also lead to highly reduced, alkaline (pH 9-12) fluids with high

83 concentrations of hydrogen, methane and formate, and which have important consequences for

84 long-term global geochemical fluxes and for biogeochemical cycles (Holm and Charlou, 2001;

85 Konn et al., 2009; Lang et al., 2018; Proskurowski et al., 2006, 2008).

86

87 The Atlantis Massif $\left(30^{\circ} \mathrm{N}\right.$, Mid-Atlantic Ridge) is one of the best-studied OCCs and hosts the 88 off-axis Lost City hydrothermal field (LCHF) on its southern wall (Fig. 1). Serpentinization 89 reactions in the underlying mantle rocks produce high $\mathrm{pH}(9-11),<91^{\circ} \mathrm{C}$ fluids that form large 90 carbonate-brucite structures upon venting on the seafloor (Kelley et al., 2001, 2005; Ludwig, et 91 al., 2006). The fluids have high concentrations of $\mathrm{H}_{2}, \mathrm{CH}_{4}, \mathrm{C}_{2}+$ alkanes and formate $\left(\mathrm{HCOO}^{-}\right)$ 92 that support novel microbial communities dominated by $\mathrm{CH}_{4}$-cycling archaea in the 
93 hydrothermal carbonate deposits (Brazelton et al., 2006; Brazelton and Baross, 2009; Lang et al.,

94 2010; Méhay et al., 2013; Proskurowski et al., 2006, 2008; Schrenk et al., 2004). Formate and

95 low molecular weight hydrocarbons in the Lost City hydrothermal vents are believed to be

96 formed by abiogenic processes during serpentinization at depth (Lang et al., 2012, 2018;

97 Proskurowski et al., 2008). Thus, the Atlantis Massif provides a natural laboratory to study the

98 links between serpentinization processes and microbial activity in the shallow subsurface of

99 ultramafic and mafic rock sequences that have been uplifted to the seafloor along a major

100 detachment fault zone (Blackman et al., 2002; Cann et al., 1997; Boschi et al., 2006; Karson et

101 al., 2006; Kelley et al., 2001, 2005; Schroeder and John, 2004). The processes controlling fluid

102 flow and a deep biosphere are intimately linked; however, the spatial scale of lithologic

103 variability, the implications for fluid flow paths and geochemical exchange, and the

104 consequences for subsurface ecosystems supported by these systems remain poorly constrained.

105

106 Here we present an overview of Expedition 357 of the International Ocean Discovery Program

107 (IODP), which cored seventeen shallow holes at nine sites (Figs. 1, 2) across the Atlantis Massif

108 (Früh-Green et al, 2016). Expedition 357 was implemented by the ECORD Science Operator

109 (ESO) as a Mission Specific Platform (MSP) expedition and consisted of an offshore phase on

110 board the RRS James Cook in fall 2015 and a two-week onshore phase at the IODP Bremen Core

111 Repository in January-February 2016 (Früh-Green et al., 2017a). A major aim of drilling was to

112 investigate seawater infiltration and alteration processes, and their influence on the nature and

113 distribution of microbial communities in lithologically heterogeneous domains of an oceanic

114 core complex. Drilling along a spreading-parallel, east-west profile with seven sites targeted the

115 serpentinite basement at varying distances away from the ridge axis and the Lost City vent field 
116 (Fig. 1, Table 1; see also Früh-Green et al., 2015). Two sites were drilled on the eastern part of 117 the southern wall (Sites M0068 and M0075), three sites in the central section north of Lost City 118 (Sites M0069, M0072, and M0076), and two sites on the western end (Sites M0071 and M0073, 119 with no recovery at M0073). This $8.5 \mathrm{~km}$ long profile allows us to explore the extent and activity 120 of the subsurface biosphere in an actively serpentinizing environment and assess how abiotic and 121 biotic processes change with aging of the lithosphere, variations in rock type, and with time of 122 exposure on the seafloor. Two further shallow sites towards the central dome of the massif (Sites 123 M0070 and M0074) targeted the mafic, plutonic domain drilled at IODP Site U1309. Penetration

124 and core recovery were limited at these northern sites, and the recovered sequences were 125 dominated by carbonate sediments and sedimentary breccias. The cores obtained during IODP

126 Expedition 357 are the first continuous sequences of fault rocks recovered along a major 127 detachment fault that has an inferred thickness of $\sim 100 \mathrm{~m}$ (e.g., Karson et al., 2006; Schroeder 128 and John, 2004). These cores provide a unique opportunity to study the interaction of 129 magmatism, deformation and fluid-rock interaction during the evolution of the Atlantis Massif 130 and the impact these processes on habitability for microorganisms.

\section{2. Expedition strategy and methods}

133 To obtain a comprehensive view of active serpentinization, fluid circulation and microbial 134 activity, a strategy was developed based on the use of seabed drills that combined coring with 135 water sampling and in situ geochemical measurements during drilling (Früh-Green et al., 2015).

136 To enable continuous operations, two seabed drills were used: the British Geological Survey 137 (BGS) RockDrill2 (RD2) and the Meeresboden-Bohrgerät 70 (MeBo) from the Center for 138 Marine Environmental Sciences (MARUM; University of Bremen, Germany). This was the first 
139 time that seabed drill technology was used in the ocean drilling program. Both drills are remotely

140 operated systems that are lowered onto the seabed, with power and control maintained from the

141 ship via an umbilical and using multiple rods and core barrels to progressively penetrate into the

142 seabed (Früh-Green et al., 2017b). They are both based on an HQ-size, diamond coring system,

143 producing between 61 and $62 \mathrm{~mm}$ diameter cores, similar in size to the standard IODP core

144 diameter, while cutting a smaller diameter hole. By sitting on the seabed, they do not require

145 heave compensation and consequently have good control on bit weight, analogous to land-based

146 coring, and bottom seawater is used as the drilling fluid.

147

148 The expedition included engineering developments that allowed continuous measurement of 149 geochemical parameters during drilling, sampling of bottom water after drilling, and the injection

150 of synthetic contamination tracers during drilling. To evaluate the composition of fluids

151 emanating from the flushed boreholes in real-time, a suite of in situ sensors mounted on the drills

152 measured dissolved oxygen, hydrogen and methane, temperature, $\mathrm{pH}$, and oxidation-reduction

153 potential (ORP) during coring operations. Bottom water was collected prior to drilling using the

154 ship's CTD Niskin bottle rosette and after drilling using Niskin bottles mounted on the drills.

155 Each rock drill was also equipped with a pump system to deliver perfluoromethylcyclohexane

156 (PFC) tracer during drilling to assess seawater contamination of the cores (Orcutt et al., 2017).

157 Shipboard sampling also evaluated contamination potential of the drilling equipment itself,

158 including greases and other lubricants. When recovered to deck, water samples were

159 immediately collected for dissolved $\mathrm{H}_{2}$ and $\mathrm{CH}_{4}$ concentration analyses, cell counts and PFC

160 tracer, which were measured onboard, and subsamples were taken for shore-based geochemical

161 and microbiological analyses (see Früh-Green et al., 2017b). Borehole plug systems were also 
162 designed to enable future sampling of borehole fluids; these were installed at Holes M0072B and

163 M0075B (Früh-Green et al., 2017b). These will be visited on a US-led research expedition in

164 September 2018 with the ROV Jason (funded by the National Science Foundation) to further

165 investigate the serpentinization and microbiological processes operating in this system.

166

167 To accomplish the microbiology related objectives of the expedition and to enable preservation

168 of ephemeral microbiological properties, whole round core (WRC) samples were collected

169 shipboard immediately after core retrieval, curation, and scanning with the multi-sensor core

170 logger. In total, 42 WRC samples were taken from the 17 holes drilled during the offshore phase

171 of the expedition, yielding nearly $8 \mathrm{~m}$ in total length and representing $\sim 14 \%$ of the entire core

172 recovered. For part of these WRCs, potentially contaminated exterior surfaces were flame-

173 sterilized on the ship in a KOACH open clean system with care to avoid potential contaminants

174 (e.g. dust). Interior pieces of rock were collected after crushing using a flame-sterilized chisel

175 and fixed for microbial cell detection (Früh-Green et al., 2017b). Subsamples of WRCs were

176 used to establish 29 different enrichment experiments on the ship, with initial indications of

177 positive activity in some of the treatments based on elevated cell counts. Remaining portions of

178 the WRCs were immediately frozen at $-80^{\circ} \mathrm{C}$ and shipped to the Kochi Core Center, Japan, at the

179 end of the offshore phase. There, exteriors of the WRCs were removed under sterile conditions

180 with a band saw system equipped in a clean booth (Orcutt et al., 2017) and the WRC interiors

181 and exteriors were subsampled for multiple shore-based analyses.

182

183 Taking advantage of weather and operational downtime, IODP Expedition 357 generated a high184 resolution multibeam bathymetry map across the Atlantis Massif. The new bathymetry, after 
185 processing, provides a grid with a resolution of $20-50 \mathrm{~m}$, which is two to five times higher

186 resolution than previously available bathymetry for this area (100 m) (Blackman et al., 2002).

187 The survey covered the entire striated detachment fault surface of the Atlantis Massif and

188 surrounding terrain, which included the ridge axis to the east, the Atlantis Fracture Zone to the

189 south, the tectonized terrain off-axis and west of the detachment, and its gradual narrowing

190 transition to the adjacent seafloor to the north (Fig. 1).

191

192 As with all IODP mission-specific platform expeditions, no cores were split during the offshore

193 phase. A comprehensive onshore phase at the IODP Bremen Core Repository complemented the

194 offshore phase, during which the cores were described in detail and the IODP minimum and

195 some standard measurements were made (see Früh-Green et al., 2017b for details). Bulk rock

196 preparation and geochemical analyses deviated from standard IODP procedure and were

197 conducted in the ultraclean laboratories of the Pacific Centre for Isotopic and Geochemical

198 Research at the University of British Columbia (Canada). Major elements were measured using

199 an inductively coupled plasma-optical emission spectrometer (ICP-OES) and trace elements

200 (including $\mathrm{Cr}$ and $\mathrm{Ni}$ ) were determined with a high-resolution inductively coupled plasma-mass

201 spectrometer (HR-ICP-MS), using international standards and an in-house standard (see

202 Geochemisty section in Früh-Green et al., 2017b).

203 


\section{Expedition highlights}

205 In brief, comparison of the recovered rock types (Fig. 2), cross-cutting relationships and the

206 newly produced bathymetric map (Fig. 1) indicate that the central sites recovered in situ

207 sequences that provide a record of (from oldest to youngest): early magmatism emplaced in the

208 shallow mantle, multiphase progressive seawater penetration, serpentinization and

209 metasomatism, dolerite intrusions, and recent basaltic volcanism. As the boreholes were located

210 across the detachment fault zone, the cores likely sampled different structural levels which were

211 tectonically transposed over the thickness of the detachment fault zone $(\sim 100 \mathrm{~m})$. The two

212 eastern Sites M0075 and M0068 and the western Site M0071 recovered fault scarp deposits. The

213 scarp deposits and rubble intervals provide no information as to the orientation of structures or

214 veins; however, the rock types, deformation and alteration characteristics, as well as contact

215 relationships preserved in coherent portions of the cores, are similar to those recovered in the in

216 situ sequences at the central sites and provide information about the magmatic, metamorphic and

217 deformation history at shallow levels of the detachment fault zone. Sedimentary breccias with

218 variably rounded clasts (predominantly basalt with some serpentinite, gabbro, and dolerite) in a

219 foraminiferous carbonate matrix were recovered at Site M0070 to the north of the east-west

220 transect, and only one short highly disturbed sediment core was recovered from Site M0074.

$222 \quad 3.1$ Multibeam bathymetry

223 New bathymetric mapping revealed a striated detachment surface with variations in geometry 224 along-axis from south to north (Fig. 1a). Near the transform wall, the detachment fault surface 225 summits near the Lost City hydrothermal field at $<800$ meters below sea level (mbsl); from there 226 it dips $\sim 8^{\circ}$ east toward the ridge axis, $\sim 6^{\circ}$ to the west, and $\sim 8^{\circ}-10^{\circ}$ to the north toward the 
central dome. The detachment deepens to the north to $>1500 \mathrm{mbsl}$. This deepening is associated

228 with a change in shape; the detachment shows curvature along the spreading direction with

229 slopes of up to $15^{\circ}$ at its termination toward the ridge axis, becomes subhorizontal, and dips up

230 to $10^{\circ}$ away from the axis.

232 The hanging wall cutoff (termination) is well preserved toward the northern, deeper part of 233 Atlantis Massif, corresponding to a sharp contact between the ridgeward-dipping striated fault 234 plane and the adjacent seafloor volcanic terrain. This volcanic terrain has a $<10^{\circ}$ tilt westward, 235 away from the ridge axis, and hosts volcanic cones and a bathymetric texture typical of volcanic 236 terrain along the rift valley floor (Fig. 1b). This portion of volcanic seafloor is bound further east 237 by a fault scarp and corresponds to the top of a back-tilted tectonic block, as previously 238 identified (Blackman et al., 2002; Cann et al., 1997).

240 The termination is not preserved to the south, ridgeward of the elevated portion of the 241 detachment. Instead, the striated surface is dissected by a major scarp, with a relief of up to 3000 $242 \mathrm{~m}$ from the rift valley floor and the top of the scarp. This scarp shows a lobate structure 243 indicating mass-wasting processes (slumping). Laterally, it links north with the fault scarp 244 bounding the tectonically uplifted volcanic seafloor, which corresponds to the present-day rift 245 valley wall fault. The striated surface is also affected by extensive mass wasting along its 246 southern boundary toward the transform valley (Fig. 1b). The mass wasting produces scarps that 247 are concave at their subvertical headwall. The transform wall south of Atlantis Massif has an 248 average slope of $\sim 20^{\circ}$ and numerous channels bound by high ridges channelling debris at the 249 base of the transform valley. Widespread mass wasting at smaller scales is also observed on 
250 steeper slopes of the detachment fault surface along the flanks of larger-scale striations. Late

251 small-slip faults (centimeters to tens of meters) cut the striated detachment surface and are

252 subparallel to oblique to the ridge axis. Most have scarps facing away from the ridge axis, with

253 scarps up to $\sim 10-20 \mathrm{~m}$ in vertical relief and which have irregular traces.

\subsection{Lithology, alteration, and structure}

\section{$256 \quad 3.2 .1$. Lithology}

257 More than $57 \mathrm{~m}$ of core were recovered, with borehole penetration depths ranging from 1.3 to $258 \quad 16.44$ meters below seafloor (mbsf). Core recoveries ranged from 23 to $75 \%$ of total penetration, 259 with $100 \%$ recovery in some intervals (Table 1; Figure 2). This significant recovery of exhumed 260 mantle peridotite at the surface of a major detachment fault zone is unprecedented in the history 261 of ocean drilling and provides a new window into understanding interlinked processes of crustal 262 accretion, deformation and alteration that to date could not be deduced with conventional rotary 263 drilling, dredging or submersible sampling. Many lithologic and intrusive contacts, deformation 264 features and alteration characteristics are preserved in the cores, even in highly fractured and/or 265 sheared intervals. The cores highlight a highly heterogeneous lateral and vertical distribution of 266 ultramafic and mafic rocks that host a range of alteration styles and extent of deformation (Figs. 2672 and 3).

269 Of the core recovered from the six sites across the southern wall (from west to east: M0071, 270 M0072, M0069, M0076, M0068, M0075; Figs. 1a and 2), serpentinized harzburgite and dunite 271 make up $44 \%$ of the core by length. Other major rock types include basaltic rocks and 272 metadolerites (combined 24\%) and schistose metasomatic rocks with varying proportions of talc, 
amphibole and chlorite (11\%). Minor lithologies include calcareous sedimentary units (8\%), and

274 gabbroic rocks (4\%). In comparison, previous dredging and Alvin dive campaigns at the

275 southern Atlantis Massif recovered a similar percentage of ultramafic rocks (45\% of total

276 samples collected), but a higher percentage of gabbroic rocks (24\%), metasomatic rocks (22\%)

277 and sediments (15\%), and less basaltic and doleritic rocks (5\%) (Schroeder and John, 2004;

278 Boschi et al., 2006a; Karson et al, 2006). The proportion of gabbro to peridotite was less than at 279 IODP Site U1309, where 1408m of gabbroic rocks were recovered; however, the proportion of 280 dolerite was comparable (Blackman et al., 2006; McCaig and Harris, 2012). A synthesis of the 281 lithological contacts, mineralogies and off shore analyses of the key sites are given in 282 Appendixes A through J.

284 The ultramafic rocks are dominated by harzburgites punctuated by intervals of dunite and minor 285 pyroxenite veins. Gabbroic rocks occur locally as zones of melt impregnation (tens of 286 centimeters thick) and veins at Sites M0068, M0071, M0072 and M0076 (Fig. 2). The 287 harzburgites and dunites exhibit protogranular textures and are extensively serpentinized. 288 Intervals of weakly porphyroclastic serpentinized peridotites were rare and localized. 289 Serpentinized dunites are found exclusively as discrete intervals alternating with harzburgite and 290 likely represent relict mantle melt channels or domains of melt-rock interaction (Kelemen et al., 291 1992; Nicolas, 1986). Mantle melt-rock reaction textures including vermicular to subhedral 292 spinels (e.g., Nicolas and Prinzhofer, 1983) and pyroxene veins were also observed. The 293 distribution of gabbro rocks is highly heterogeneous downhole and there was an absence of 294 continuous, coherent sections of gabbroic core. Rare magmatic fabrics characterized by diffuse 295 but planar centimeter-scale banding/layering of igneous minerals in gabbroic rocks were 
recovered in Hole M0068B. Dolerite intrusions, basaltic rocks and local domains of

297 hyaloclastites represent the latest stage of magmatic activity. Metamorphosed dolerite intrusions

298 ranging from a few $\mathrm{cm}$ to several meters in thickness were recovered at the central and eastern

299 sites, and some dolerite intervals in Hole M0075B show chilled margins against fault rocks (see

300 Fig. F5 in Früh-Green et al., 2017c). Dolerites and metadolerites as well as poorly vesicular

301 aphanitic to microcrystalline basalts with glassy margins also occur as mm-dm sized components

302 within the sedimentary breccias. The dolerites were variably altered, while basalts were often

303 fresh, with no sign of metamorphism.

304

305 All types of variably altered and deformed ultramafic and mafic rocks occur as clasts in

306 sedimentary breccias overlying the basement sequences and as fault scarp deposits. The

307 sedimentary cap rocks include basaltic breccias with foraminiferous carbonate sand and/or

308 lithified foraminiferous carbonate matrix. Fresh and partially palagonitized glass in basaltic

309 components and hyaloclastites were observed in some of the breccias and in some cores

310 containing carbonate sediment.

$312 \quad 3.2 .2$ Serpentinization and metasomatism

313 The IODP Expedition 357 cores reveal a high degree of alteration and intervals with variable

314 metasomatic overprinting in the ultramafic rocks. Different types of alteration are distinguished

315 depending on protolith: serpentinization, talc-amphibole-chlorite metasomatism and oxidation in

316 the ultramafic rocks; and hydration, oxidation, and local Ca-metasomatism/chloritization along

317 contacts between doleritic and gabbroic domains and serpentinites. The sequence of alteration 
318 textures and the associated mineralogical assemblages vary between sites and downhole in some 319 cases (Früh-Green et al., 2017c, d,e and f).

321 Serpentinization is common in the ultramafic rocks at all sites and occurs as pervasive alteration 322 with extensive to complete replacement of the primary mineralogy, forming mesh textures after 323 olivine, bastites (lizardite \pm chrysotile) after orthopyroxene, and different generations of 324 serpentine veins (Fig. 4). A detailed study of the textures and mineralogies of the serpentinized 325 serpentinites combined with in situ major and trace element analyses in primary phases and 326 serpentine minerals is given in Rouméjon et al. (2018). These are used to make a model for the 327 development of alteration heterogeneities at the Atlantis Massif and are summarized briefly here.

328 Hydration of olivine led to a typical serpentine mesh texture, which is characterized by mesh 329 cells, tens to hundreds of microns in size, delimited by microfractures that initially crosscut the 330 olivine. Lizardite mesh rims form the outer part of cells, whereas the mesh cores are made up of 331 poorly crystallized lizardite and/or chrysotile. Magnetite tends to crystallize in the mesh rims and 332 concentrates along microfractures. Progressive fluid infiltration and serpentinization is evident 333 by recrystallization of mesh textures to chrysotile-polygonal serpentine or antigorite, and by 334 multiple sets of veins with variable infillings (Fig. 4; see also Rouméjon et al., 2018). The 335 orthopyroxenes also show overprinting relationships with replacement by serpentine, talc, 336 tremolite and/or chlorite.

338 Although the depth of penetration was limited, the abundance of gabbroic intrusions appears to 339 increase from west to east and is associated with talc-amphibole-chlorite metasomatism and in 340 some cases chlorite blackwall formation. Multiple generations of amphibole are observed in the 
341 gabbroic domains, reflecting progressive alteration from amphibolite to greenschist-facies

342 conditions during exhumation, as described in previous studies (Schroeder and John, 2004;

343 Boschi et al., 2006a). Metasomatism is characterized by varying proportions of talc, chlorite and

344 tremolitic amphibole and is a common feature at the central and eastern sites, evident as pale

345 greenish-white domains or vein networks (Figs. 3b and d). Talc-metasomatism is rare at the

346 western Site M0071 and is most prevalent in Hole M0072B near Lost City (Fig. 2). It develops

347 both as pervasive, irregular patches in the serpentinites or as localized alteration associated with

348 mafic intervals, enclosing serpentinized harzburgite on centimeter to decimeter scales (Figs. 5

349 and 6). The metasomatic domains are locally deformed and the talc-rich zones are commonly

350 sheared, forming intervals of talc-amphibole-chlorite schists. Talc generally replaces mesh

351 textures or forms in veins in the serpentinites, whereas tremolitic amphibole and chlorite

352 assemblages are found in mafic domains and at contacts between serpentinite and gabbro or

353 metagabbro, or in domains that have been infiltrated by mafic melts (Figs. 5 and 6). In some

354 sections, amphibole and chlorite appear to have formed prior to talc. Relict olivine is also found

355 in a number of cores in the central and eastern sites (Holes M0068, M0072, M0076) where talc-

356 amphibole-chlorite metasomatism and/or chlorite-rich alteration is most prevalent.

358 Metasomatism is particularly pronounced in Hole M0072B, where complex zoned intervals

359 (approximately $5 \mathrm{~cm}$ thick) with mafic lenses adjacent to chlorite-rich blackwalls are repeatedly

360 present over a few meters. Exceptional relationships between mafic intrusions (possibly doleritic

361 or microgabbro), talc \pm amphibole \pm chlorite zones, and serpentinized dunite and harzburgite are

362 observed in Cores M0072B-6R1 (Fig. 5d) and M0072B-7R1 (Fig. 6). The mafic intrusions in

363 these cores have pale brown to pinkish-brown central domains that are surrounded by external 
364 dark green domains made up mostly of chlorite (chlorite blackwall), which in turn grade into

365 talc-amphibole-rich domains at the contact to the serpentinites. The pinkish brown domains were

366 originally described as rodingites (Früh-Green et al., 2017d), which have been found during

367 previous sampling campaigns along the southern wall of the Atlantis Massif (Boschi et al.,

368 2006a). However, subsequent analyses have yet to identify typical Ca-Al silicates, such as

369 epidote (clinozoisite), diopside, prehnite, (hydro)garnet or vesuvianite, which are commonly

370 found in rodingites in similar associations with serpentinites. Instead, preliminary X-ray

371 diffraction (XRD), micro-Raman spectroscopy and microprobe analyses (unpublished data)

372 indicate that these zones are indeed Ca-rich but are made up of chlorite and fine-grained

373 aggregates of anorthite \pm tremolitic and/or pargasitic amphibole. The association of chlorite and

374 anorthite in these domains could result from higher temperatures of alteration than are typically

375 associated with rodingite $\left(>\sim 350^{\circ} \mathrm{C}\right)$. Anorthite may also form from fluids with higher $\mathrm{CO}_{2}$

376 concentrations (Rice, 1983).

377

378 Although brucite occurs in the actively venting carbonate structures at Lost City (Kelley et al.,

379 2001; Früh-Green et al., 2003; Ludwig et al., 2006) and is a common product of serpentinization

380 reactions, it has not been found in previous studies of the basement rocks of the Atlantis Massif

381 (e.g., Boschi et al., 2006a; 2008). In the IODP Expedition 357 cores, brucite could not be

382 detected visually, microscopically or with XRD on bulk rock samples (Früh-Green et al.,

383 2017c,d,e). In addition, a brucite signature is absent in micro-Raman spectra, which together

384 with nearly stoichiometric serpentine compositions of the mesh texture serpentine minerals

385 (Rouméjon et al., 2018; Rouméjon et al., this issue) strongly suggest that brucite is absent in the 386 serpentinized peridotites that make up the southern wall of the Atlantis Massif. The absence (or 
387 dissolution) of brucite and abundance of talc in the metasomatic assemblages may be a

388 consequence of high $\mathrm{Si}$ activities in the fluids during progressive hydrothermal alteration along

389 the detachment fault zone and/or high alteration temperatures (above $350^{\circ} \mathrm{C}$ ) during denudation

390 of the mantle.

392 Finally, later-stage oxidation of the serpentinized harzburgites and dunites is characterized by

393 reddish to brown alteration, occurring as both pervasive and localized features, and is commonly

394 associated with calcium carbonate veins (Fig. 3a). Overprinting relationships in the ultramafic

395 rocks demonstrate an overall progression from local amphibole-chlorite alteration to

396 serpentinization to talc \pm amphibole \pm chlorite metasomatism and later oxidation.

397

398 Hydration of the dolerites and basalts manifests as pervasive background alteration with

399 moderate to high intensity accompanied by alteration halos that flank veins. Secondary minerals

400 vary depending on the temperature of alteration, with dolerites dominated by greenschist-facies

401 minerals (chlorite, amphibole, and epidote), and basalts by low-temperature oxidation to iron

402 oxyhydroxides and clays. Epidote occurs as a dominant vein mineral in metadolerites in Hole

403 M0069A often with vein halos dominated by chlorite. Chilled margins in dolerite dikes that have

404 intruded into talc-amphibole-chlorite schists are observed at the most eastern Site M0075.

405 Hydration of gabbros is generally associated with chlorite-amphibole assemblages.

406

407 Hydrothermal veins are present in all rock types. Vein minerals include serpentine, talc, chlorite, 408 amphibole, epidote, quartz, and calcium carbonate. The veins are often complex, with multiple 409 infillings and internal textures, highlighting a protracted formation history. Crosscutting 
410 relationships are also complex, with the same veins observed both crosscutting and being

411 crosscut by a second vein type. The occurrence of calcium carbonate veins was surprisingly

412 limited in the recovered cores. Carbonate veins are more prevalent in the sites around the Lost

413 City hydrothermal field, where they occur mostly within entirely serpentinized dunites and

414 harzburgites. At the western Site M0071, calcium carbonate veins in the serpentinites predate

415 fractures that are infilled with foraminiferous carbonate sand (Fig 3a), suggesting open fractures

416 at the top of the detachment fault zone, as described by Schroeder et al. (2002) based on Alvin

417 dive samples.

418

$419 \quad$ 3.2.3 Structures and deformation history

420 The drilled sites are located along a roughly spreading-parallel, $8.5 \mathrm{~km}$ transect (west-east) in 421 various positions (trough or wall/flank) relative to individual corrugations of the detachment 422 fault over the southern wall of Atlantis Massif (Fig. 1). Despite the fact that a number of the 423 holes recovered rocks that are considered not to be in situ, generalizations can be made about the 424 structural history recorded (Früh-Green et al., 2017c,d,e,f). As in IODP Hole U1309D at the 425 central dome of the Atlantis Massif (Blackman et al., 2006), strongly deformed microstructures 426 formed at high temperatures are rare in the IODP Expedition 357 cores. The majority of the 427 recovered cores show amphibolite- to greenschist-facies, semibrittle and brittle deformation 428 (Figs. 3 and 6), which contrasts with previous studies of samples recovered by submersible and 429 by dredging that document higher temperature, high strain conditions in parts of the southern 430 wall of the massif (Boschi et al., 2006a; Karson et al., 2006; Schroeder and John, 2004). Fault 431 rocks in shear zones preserved in the cores are dominated by anastomosing intervals of variable 432 intensity, with schistose amphibole \pm talc \pm chlorite zones up to tens of centimeters thick. The 
433 schistose shear zones contain undeformed dolerite intrusions with preserved chilled margins;

434 elsewhere, dolerite sheets record brittle and semibrittle deformation textures indicating repeated

435 magmatism and faulting. Extensive intervals of flattened breccia are associated with dolerites but

436 often contain clasts of fault rocks derived from other lithologies. Some breccia clasts show relicts

437 of higher temperature amphibolite facies deformation, as do serpentinized intervals in the

438 margins of talc-tremolite-chlorite schist zones. Intense cataclastic intervals and possible fault

439 gouge occur within some breccias and also as thin intervals within the schistose shear zones.

440 Discrete fault planes occur in most cores with a range of orientations, but lineations are generally

441 shallow on both steep and shallow fault planes. An important observation is that the serpentinites

442 are almost invariably statically altered, with no schistose serpentine developed and only

443 occasional cataclastic seams. Strain within serpentinite intervals seems to be almost entirely

444 localized within metasomatic talc-tremolite-chlorite horizons.

$446 \quad 3.3$ Bulk rock geochemistry

447 A wide range of major and trace element bulk rock compositions reflect the differences in rock 448 type as well as the type and extent of alteration (Table 2, Figs. 7, 8 and 9). Independent of site 449 location, the talc-amphibole-chlorite schists typically have high $\mathrm{SiO}_{2}$ contents, ranging from 50$45060 \mathrm{wt} \%$, and low $\mathrm{MgO} / \mathrm{SiO}_{2}$ ratios $(0.45-0.51)$ as well as lower loss on ignition (LOI: $4.3-5.3$ $451 \mathrm{wt} \%$ ) than the serpentinites (LOI: $11.95-13.8 \mathrm{wt} \%$ ). The serpentinized ultramafic rocks have 452 the highest $\mathrm{MgO} / \mathrm{SiO}_{2}$ ratios $(0.96$ - 1.19) and variable but high $\mathrm{Cr}$ (up to 29,698 ppm in Hole 453 M0069) and Ni (up to 14,590 ppm in Hole M0071A) contents. Overall, the talc-amphibole454 chlorite schists (and in some cases the impregnated/metasomatized ultramafic rocks) are richer in $455 \mathrm{Al}_{2} \mathrm{O}_{3}, \mathrm{Na}_{2} \mathrm{O}, \mathrm{CaO}, \mathrm{TiO}_{2}$, and depleted in $\mathrm{Fe}_{2} \mathrm{O}_{3}$ (Fig. 7). The talc schists are also enriched in $\mathrm{Cr}$ 
and $\mathrm{Ni}$ relative to the gabbroic rocks and dolerites but have lower concentrations than the

457 ultramafic lithologies (Fig. 8). Samples from Hole M0068B exhibit the highest $\mathrm{SiO}_{2}, \mathrm{CaO}_{\text {, and }}$

$458 \mathrm{Na}_{2} \mathrm{O}$ contents, but the lowest $\mathrm{Al}_{2} \mathrm{O}_{3}$ and $\mathrm{Fe}_{2} \mathrm{O}_{3}$ contents. The most altered dolerites and gabbros

459 have characteristically low $\mathrm{SiO}_{2}$ concentrations $(26.2-31.6 \mathrm{wt} \%)$, high $\mathrm{Fe}_{2} \mathrm{O}_{3}(18.8-32.1$ wt $\%)$

460 and low $\mathrm{Ni}$ and $\mathrm{Cr}$ (Fig. 8), which reflects the high modal abundance of chlorite in these rocks

461 and suggests Si mobility and loss during alteration (Fig. 9). The Mg and Ni concentrations of the

462 IODP Expedition 357 serpentinites and impregnated serpentinites are higher than those

463 recovered during IODP Expeditions 304-305 and likely reflects the more primitive nature of the

464 mantle peridotites recovered along the southern wall. The gabbroic compositions are similar to

465 the IODP Hole U1309D gabbros, but the dolerites and metadolerites have higher Ni

466 concentrations and may be the result of a higher primary modal abundance of olivine (Fig. 9).

468 The Rare Earth Element (REE) patterns group by lithology and show a weakly defined

469 enrichment from west to east (Fig. 10) and some variations downhole. The serpentinized

470 ultramafic rocks have relatively flat to slightly light REE (LREE) depleted chondrite-normalized

471 patterns (i.e., typically centered around 1 or below). The impregnated/metasomatized

472 serpentinites from Hole M0072B exhibit values slightly higher than 1 . Dolerites and gabbros

473 exhibit moderate LREE depletions with values ranging between 1 and 10. Two of the talc-

474 amphibole-chlorite schists have REE patterns resembling the impregnated/metasomatized

475 samples. Positive and negative europium anomalies were observed but do not correlate with a

476 particular lithology or site. Along with correlated Mg\# and Ni abundances (Fig. 8), geochemical

477 trends in the serpentinized ultramafic rocks include a common uranium positive anomaly (the

478 intensity of which decreases in impregnated / metasomatized samples) (Früh-Green et al., 
$4792017 \mathrm{c}, \mathrm{d}, \mathrm{e})$ and enriched lithium, cerium, and strontium anomalies in the central sites (Table 2).

480 Such anomalies are commonly related to alteration processes, either from hydrothermal

481 alteration or from late interaction with seawater on the seafloor. Rouméjon et al. (2018)

482 document regional trends in trace and REE element compositions in serpentine minerals

483 compared to primary olivine and attribute the regional and downhole variations to mobilization

484 of elements during the successive stages of exhumation as a result of early melt emplacement,

485 serpentinization-related fluid-rock interaction, and later fluid-rock interaction. LREE

486 enrichments due to the proximity with metagabbros or metadolerites are particularly observed in

487 samples from Holes M0068B and M0072B (see also Boschi et al, 2006a) and contribute to the 488 downhole variations.

$490 \quad 3.4$ Volatile concentrations

491 Elevated bottom water gas concentrations recorded by the sensor package and water sampling 492 confirmed that serpentinization is on-going at the Atlantis Massif (Figs. 11 and 12). Water 493 samples before and after drilling indicated "hot spots" of dissolved hydrogen over Sites M0068, 494 M0072, M0069, M0070 and M0071, with the highest concentrations of $323 \mathrm{nM}$ measured in 495 Hole M0072B. Elevated concentrations of methane were found over Sites M0072, M0070, and 496 M0071 (Fig. 11, Table 1; see also Table T12 in Früh-Green et al., 2017c). A CTD cast directly 497 over the Lost City hydrothermal vents (Site M0072) just south of the central drill sites had 498 significantly elevated methane and hydrogen (35-48 nM and 196-267 nM, respectively). On a 499 regional scale, hydrogen concentrations tended to be highest in the central sites and at the eastern 500 Site M0068, which may reflect active serpentinization in the vicinity of the Lost City

501 hydrothermal field (Fig. 11; Table 1). However, the interpretation of the regional-scale influence 
502 on methane and hydrogen fluxes out of the basement is ambiguous since the depth of penetration

503 into the basement was limited to $<20 \mathrm{mbsf}$.

505 In addition to elevated dissolved gas concentrations measured in the fluids, gas bubbles were 506 observed issuing from the hole and around the drill base during operations at Site M0070, even 507 when coring had stopped (Fig. 13). The bubbles could not be sampled directly with the seabed 508 drills and thus their composition remains unknown. Bathymetry indicates that Site M0070 lies 509 west of the western limit of the preserved striated detachment surface of Atlantis Massif (Fig. 1) 510 at the foot of a $\sim 30 \mathrm{~m}$ high irregular mound (Figure F2A in Früh-Green et al., 2017f). The three 511 holes penetrated the same structural unit composed of either loose or cemented basalt clasts with 512 vesicles and glass within a carbonate matrix. The mound is likely a volcanic cone that has 513 undergone faulting and/or mass wasting and, thus, we cannot exclude volcanic gases as a source 514 of the bubbles observed at this site.

516 In addition to the water sampling observations, the drill-mounted sensors recorded peaks in 517 methane and $\mathrm{pH}$ that correlated with sharp decreases in oxidation-reduction potential (ORP) at 518 many sites (Figure 12, Früh-Green et al., 2017c,d,e,f). Low ORP (or Eh) reflects reducing 519 conditions and can be interpreted as elevated hydrogen concentrations and/or other reduced 520 components (such as reduced iron and hydrogen sulphide) in the fluid. The ORP sensor does not 521 respond to methane. In some cases, excursions in the sensor signals were observed while 522 drilling, which suggests that horizons that were penetrated released reduced basement fluids and 523 volatiles into the drilling fluid. In other cases, we observed variations in the methane, $\mathrm{pH}$ and 524 ORP signals even when no drilling operations were underway or when the drills touched down 
525 on the seabed, suggesting that diffuse reduced fluids may be present at the top of the massif. In

526 many cases we observed strong negative spikes in the ORP signals without a corresponding

527 methane signal, which points to hydrogen and/ or other reduced phases being released into the

528 drilling fluids. Due to limited core recovery, we were not able to clearly correlate the excursions

529 in sensor data with specific horizons or rock types. On a regional scale, negative spikes in ORP

530 were observed in most of the holes in the central sites, which is consistent with the higher

531 dissolved $\mathrm{H}_{2}$ and $\mathrm{CH}_{4}$ concentrations at these sites and may reflect hydrothermal circulation

532 related to the Lost City hydrothermal field.

533

534 It is worth noting that the dissolved methane concentrations were monitored with a Franatech

535 METS sensor. Post-cruise evaluation of this sensor revealed that it responds to both $\mathrm{CH}_{4}$ and $\mathrm{H}_{2}$

536 with a response factor of 1 to 0.02 , respectively. This complicates interpretations of the output of

537 this sensor because $\mathrm{H}_{2}$ concentrations typically exceed those of $\mathrm{CH}_{4}$ in this environment. For

538 example, in Lost City hydrothermal fluids, the $\mathrm{H}_{2} / \mathrm{CH}_{4}$ ratio varies from 0.5 to 9.2 (Proskurowski

539 et al, 2008). Where we measured bottom water concentrations from CTD casts, $\mathrm{CH}_{4}$ was often

540 below our detection limit $(0.7 \mathrm{nM})$; however, at some sites both $\mathrm{H}_{2}$ and $\mathrm{CH}_{4}$ were present and the

$541 \mathrm{H}_{2} / \mathrm{CH}_{4}$ ratio ranged from 5.5 to 20.9 . In samples taken in the Lost City plume, the average ratio

542 was 5.3. Samples from the drill-mounted Niskin bottles yielded $\mathrm{H}_{2} / \mathrm{CH}_{4}$ ratios ranging from 1.2

543 at Site M0070A to 167 at Site M0068B (see Table T12 in Früh-Green et al., 2017c). Although

544 we were unable to make quantitative estimates of volatile concentrations from the sensor data,

545 the METS sensor likely recorded both $\mathrm{H}_{2}$ and $\mathrm{CH}_{4}$, and it is possible that the output values we

546 observe represent $\mathrm{H}_{2}$ concentrations that are a factor of 50 times higher than the actual recorded 
547 values given as $\mathrm{CH}_{4}$ concentrations. Horizons with high $\mathrm{H}_{2}$ concentrations are also indicated by

548 the fact that elevated $\mathrm{CH}_{4}$ signals often correlated with strong decreases in ORP.

$550 \quad 3.5$ Microbiology sampling

551 To accomplish the microbiology-related objectives of the expedition, an extensive program was

552 carried out on board the ship to collect whole-round core samples immediately after core

553 retrieval, curation, and scanning with the multisensor core logger to enable preservation of

554 ephemeral microbiological properties. This program included (1) frozen preservation of core

555 material for DNA- and lipid-based analyses in shore-based laboratories, (2) establishment of

556 enrichment incubations on the ship (at ambient or in situ pressure) to assess the potential for

557 various microbial metabolisms, (3) collection of samples to evaluate the performance of the

558 contaminant tracer delivery, (4) preservation of samples for biomass determination via cell

559 counting, and (5) collection of parallel samples for spatial and isotopic geochemical

560 determination, particularly focused on carbon and minerals.

562 A major technical development for this expedition to enable microbiological analysis was

563 establishing the delivery system for adding a synthetic tracer (PFC) into the drilling fluids to

564 monitor the possibility of drilling-induced contamination (Orcutt et al., 2017). Samples of core

565 barrel liner fluids, sensor package Niskin bottles, and exterior and interior pieces of whole-round

566 core were collected to quantify the concentration of PFC tracer added during drilling operations

567 and track its potential distribution into samples. After overcoming some technical difficulties

568 with the metering pump in the delivery system, we established that PFC was delivered at

569 saturating (>1 mg/L) concentrations into the drilling fluids (Orcutt et al., 2017). Moreover, 
570 appropriate handling conditions combined with coherent core samples resulted in the absence of

571 tracer from the interior of core samples (whereas less coherent materials suffered potential

572 contamination from intrusion of tracer). Overall, implementation of the tracer injection system

573 for seabed drill systems proved to work, and PFC concentrations on the exterior and interior of

574 core samples could be used as a measure to assess the quality of the sample material for detailed

575 microbiological and geochemical analyses (Orcutt et al., 2017).

576

577 To obtain an initial assessment of microbial biomass in the core samples, cell abundance was

578 determined on the ship and onshore at the Kochi Core Center (Japan) in an ultraclean laboratory.

579 Direct counting was made with an epifluorescence microscope following cell separation from

580 flame sterilized interior portions of subsamples. To enable low levels of cell detection, great care

581 was taken onshore and offshore to minimize contamination of samples (Früh-Green et al., 2017b;

582 Morono et al., 2017), resulting in a limit of detection of 9.8 cells $\mathrm{cm}^{-3}$. Cell abundance in the

583 core samples was variable and relatively low, ranging from tens to thousands of cells $/ \mathrm{cm}^{3}$, with

584 many of the basement samples often below the minimum quantification limit of $9.8 \mathrm{cells}^{-3}$

585 (Fig. 14). Cell counts in the interior portions of the basement rocks ranged from <10 to $6.5 \times 10^{2}$

586 cells $\mathrm{cm}^{-3}$, with one sample from Hole M0071A yielding $4.1 \times 10^{3}$ cells $\mathrm{cm}^{-3}$. Excluding the

587 short core obtained at Site M0074 (because of contamination issues with core handling), the

588 highest cell counts were found in the sediments in Hole M0069A near the contact to the

589 basement, reaching up to $1.6 \times 10^{4}$ cells $\mathrm{cm}^{-3}$ at $5.46 \mathrm{mbsf}$, and decreased rapidly to $<10^{2}$ cells

$590 \mathrm{~cm}^{-3}$ in the underlying basement rocks. The deepest samples were from this hole (at $14.6 \mathrm{mbsf}$ ),

591 where $10-24$ cells $\mathrm{cm}^{-3}$ were measured in the serpentinites. A similar trend was observed at Hole 
592 M0072B, with up to $5 \times 10^{2}$ cells $\mathrm{cm}^{-3}$ within the top meter of the hole and decreasing to $<20$

593 cells $\mathrm{cm}^{-3}$ below 6.5 mbsf (Fig. 14).

594

595 The cell densities in the IODP Expedition 357 drill cores are distinctly lower than in the actively

596 venting Lost City carbonate towers $\left(10^{7}\right.$ to $10^{8}$ per gram of wet weight; Kelley et al., 2005). They

597 are also low in comparison to cell densities in fluids sampled in actively serpentinizing

598 environments on land, which are typically less than $10^{5}$ cells ml ${ }^{-1}$, and as low as $10^{2}$ cells $\mathrm{mL}^{-1}$,

599 although continental sites of serpentinization represent different niches within the subsurface

600 ecosystem (e.g., Schrenk et al., 2013; Brazelton et al., 2017). These cell densities are also lower

601 than in mafic subseafloor cores, which have been estimated at $\sim 10^{4}$ cells per gram of rock

602 (Jørgensen and Zhao, 2016). Overall, the strict sampling handling protocols allowed for very

603 low limits of microbial cell detection, and our results show that the Atlantis Massif subsurface

604 contains a relatively low density of microbial life compared to other subseafloor crustal and

605 serpentinizing systems. This low density suggests that something may be limiting life in this

606 subsurface habitat compared to the other habitats, such as energy availability, high pH, or low

607 carbon dioxide availability, but further analyses are required to determine this.

608

609 4. Implications for understanding oceanic core complex processes

610 Expedition 357 was the first IODP expedition to successfully use seabed drills to acquire intact

611 shallow mantle sequences at the top of the footwall of an oceanic detachment fault zone and to

612 monitor borehole fluids while drilling. This expedition provides insights into magmatic, tectonic

613 and alteration processes of an oceanic core complex that is actively undergoing serpentinization

614 and has the potential to sustain a unique subsurface biosphere. The cores have exceptionally 
615 well-preserved contacts and show strong lateral and vertical variations (from $\mathrm{cm}$ to $\mathrm{m}$ scale) in

616 rock type and alteration assemblages that are a consequence of multiple phases of magmatism,

617 fluid-rock interaction and mass transfer along the detachment fault zone. The results of this

618 expedition are expected to address fundamental questions that were part of the motivation for the

619 expedition (Früh-Green et al., 2015), such as: How are seafloor spreading and mantle melting

620 linked to ocean crustal architecture? How do oceanic detachment faults develop and facilitate

621 hydrothermal circulation? How do they affect the development of alteration patterns and the

622 evolution of the deep biosphere in these environments?

623

624 IODP Expedition 357 sampled only the very shallowest level of the detachment fault zone and

625 overlying talus blocks at the top of the massif. However, this is the first time that clear

626 relationships of gabbro and dolerite hosted by mantle peridotite along the southern wall of

627 Atlantis Massif have been documented. These relationships imply that melts are generated

628 beneath volcanic-poor ridge segments at ridge-transform intersections, but much of the melt may

629 be trapped in the mantle as it turns into lithosphere beneath the ridge axis, rather than migrating

630 upward to form a continuous magmatic crust. Based on high-resolution ion microprobe (i.e.,

631 SHRIMP) U-Pb zircon ages from IODP Hole 1309D and broadly spaced samples collected along

632 the southern ridge of Atlantis Massif, Grimes et al. (2008) document a protracted history of

633 accretion in the footwall. They calculate a detachment fault slip rate of $28.7 \pm 6.7 \mathrm{~mm} / \mathrm{a}$, which

634 implies significant asymmetric plate spreading (up to $100 \%$ on the North American plate) for at

635 least 200 ka during core complex formation. Our results are consistent with previous studies that

636 indicate that ongoing magmatic activity associated with asymmetric plate spreading results in a

637 heterogeneous mafic and ultramafic lithosphere with late dolerite intrusions exposed in the 
638 denuded footwall, whereas accretion of volcanic seafloor persists in the hanging wall (Cannat et

639 al., 2006; Grimes et al., 2008; Ildefonse et al., 2007; John and Cheadle, 2010; Karson et al.,

640 2006; McCaig and Harris, 2012; Smith et al., 2006).

641

642 The volume of gabbros in the southern wall of the Atlantis Massif and their mode of intrusion as

643 thin lenses are distinct from the thick gabbroic sequence recovered at IODP Site U1309 (IODP

644 Expeditions 304 and 305) at the central dome (Blackman et al., 2006; Ildefonse et al., 2007;

645 McCaig et al., 2010; McCaig and Harris, 2012). Although a direct comparison of the two drilling

646 campaigns is difficult to make because of depth of penetration, and the possible tectonic control

647 on emplacement of rock sections, both campaigns yield important information about accretion

648 and alteration processes as well as regional heterogeneities associated with the architecture and

649 evolution of OCCs. The surface of the central dome was cored at IODP Hole U1309B, where

650 dike rocks and basalts were recovered, and a few pebbles of talc schist together with highly

651 altered basalt and dolerite were recovered in IODP Hole U1309H (Blackman et al., 2006; John et

652 al 2009). In addition, Alvin sampling during cruise AT3-60 in 2000 (MARVEL expedition;

653 Blackman et al., 2002) recovered one talc schist sample (sample 3642-1309; see Boschi et al.,

654 2008) along dive tracks in the vicinity of IODP Site U1309. Metasomatic talc-amphibole-chlorite

655 rocks are considered key components of detachment fault zones (e.g., Escartin et al., 2003;

656 Boschi et al., 2006a,b; McCaig et al., 2010) and pre-date dolerite diking events and basaltic

657 eruptions (Karson et al. 2006; McCaig and Harris, 2012). Although not abundant, the occurrence

658 of talc schists in the central dome of the Atlantis Massif hints at the presence of a thin

659 detachment fault zone in this area. However, on a regional scale, the newly acquired multibeam 
660 data (Fig. 1) clearly allow the corrugated surface related to the detachment fault zone to be

661 distinguished.

662

663 The mineralogical assemblages, alteration textures, and bulk rock chemistries recorded in the

664 IODP Expedition 357 drill cores indicate progressive seawater infiltration along the detachment

665 fault and into the footwall, pointing to an important role of the mafic intrusions in controlling

666 fluid chemistry and metasomatism. Early high temperature, amphibolite-facies alteration and

667 ductile deformation features have been reported from studies of dredged and submersible

668 sampling of the southern wall (Boschi et al., 2006a; Karson et al., 2006; Schroeder and John,

669 2004), but such features are less common in the IODP Expedition 357 drill cores. In contrast,

670 alteration in the shallow IODP Expedition drill cores is dominated by serpentinization processes,

671 brittle deformation and mass transfer between mafic and ultramafic lithologies under

672 greenschist-facies conditions.

673

674 The occurrence of gabbroic intrusions is associated with talc-amphibole-chlorite metasomatism

675 and local blackwall formation and appears to increase from west to east. Metasomatism and talc

676 precipitation are most prevalent at contacts between mafic and ultramafic domains (Figs. 5 and

677 6.). A systematic overprinting of serpentinite by talc- and chlorite-rich assemblages is associated

678 with the occurrence of variably thick (micro)gabbroic lenses and points to silica mobility and

679 channelled fluid flow at varying depths within the detachment fault zone (see also Boschi et al.,

680 2006, 2008). The geochemical influence of the gabbroic intrusions and progressive fluid-rock

681 interaction is also evident from REE enrichments measured in serpentine minerals and tends to

682 increase from west to east (Rouméjon et al., 2018). The general trend to slightly larger volumes 
683 of gabbroic intrusions from west to east (assuming the position of the drill holes roughly reflect

684 differing original depths in the lithosphere) suggests that magmatic activity may have been

685 greater at depth within the detachment fault zone before emplacement to their current locations.

686

687 The textural sequences and mineralogical assemblages in the ultramafic rocks reveal a transition 688 between an initial pervasive phase of hydration along grain boundaries to produce mesh-textures 689 in the serpentinites, with subsequent serpentinization and metasomatism focused along localized 690 fluid pathways (Rouméjon et al, 2018). Alteration commences as the peridotites and gabbros are 691 subjected to active hydrothermal circulation, but alteration of the dominant phase, olivine, to 692 produce serpentine minerals will be limited to temperatures below approximately $500^{\circ} \mathrm{C}$ 693 (Chernosky, 1973). Serpentinization of olivine becomes more effective below 350-400 ${ }^{\circ} \mathrm{C}$ 694 (Evans, 2004) and reaches maximum rates between $250^{\circ}-300^{\circ} \mathrm{C}$ (Andreani et al., 2007; Martin 695 and Fyfe, 1970; Malvoisin et al., 2012; McCollom 2016). Hydration is intense directly along the 696 detachment fault zone, where permeability is expected to be highest (McCaig et al., 2007;

697 McCaig et al., 2010), and progresses inside the footwall. When the fluids reach temperatures 698 below $\sim 350^{\circ} \mathrm{C}$, efficient serpentinization commences and is recorded by the development of 699 mesh texture at all sites. Based on zircon analyses and multicomponent magnetic remanence data 700 in the central dome, Schoolmeesters et al. (2012) proposed a model for the thermal structure of 701 the Atlantis Massif in which the $350^{\circ} \mathrm{C}$ isotherm corresponds to a depth of approximately $5 \mathrm{~km}$ 702 below the surface. Thus, initiation of serpentinization would have occurred at significant depths 703 and early in the exhumation history of the massif. The infiltration of seawater-derived 704 hydrothermal fluids is facilitated by the closely-spaced microfracture networks that crosscut the 705 olivine and result from combined thermal and tectonic stresses, enhanced by reaction-induced 
706 permeability at the onset of serpentinization (Rouméjon and Cannat, 2014; Rouméjon et al., 707 2018). As the footwall reaches shallower crustal levels, fluid flow will likely be dominated by 708 more continuous fracture planes that can channel hydrothermal fluids through the peridotite and 709 form veins (Andreani et al., 2007; Rouméjon et al., 2018). The transition from more pervasive 710 grain-boundary flow to localized or channeled flow is indicated by recrystallization of the mesh 711 texture to chrysotile-dominated serpentine and by banded veins (Rouméjon et al., 2018;

712 Rouméjon et al., this issue).

714 Talc formation postdates an early phase of serpentinization, and in some cases amphibole 715 formation (see also Boschi et al., 2006a), but predates late-stage intrusions and alteration of some 716 dolerite dikes and the extrusion of basalt, indicating that basaltic magmatism continued as the 717 variably altered basement sequences where emplaced on the seafloor. Alternating metasomatic 718 and serpentinized domains as well as irregular cross-cutting vein relationships in the IODP 719 Expedition 357 cores from the central (M0072 and M0076) and eastern sites (M0068) emphasize 720 the dynamic nature of the system with similar composition of veins forming at multiple times.

721 Textural relationships and the lateral and vertical distribution of metasomatic assemblages

722 indicate that $\mathrm{Si} \pm \mathrm{Ca} \pm \mathrm{Al}$ mass transfer occurred locally at peridotite/gabbro or

723 peridotite/dolorite contacts as well as through infiltration and interaction with Si-rich fluids along 724 fractures to form talc-rich assemblages (see also Boschi et al., 2006a; McCaig et al., 2010;

725 Rouméjon et al., 2018). In addition, the volume of carbonate veins was surprisingly low in the 726 recovered cores, even in the sites directly above the Lost City hydrothermal field. This suggests 727 that present-day fluid flow and hydrothermal activity at Lost City is localized by late normal 728 faults that cut the southern wall (Denny et al., 2015). 
730 The presence of the mafic lenses within the serpentinites - and their alteration products to

731 mechanically weak minerals, such as talc, serpentine and chlorite - may also be critical to the

732 development of the detachment fault zone and may enhance unroofing of upper mantle

733 peridotites and lower crustal gabbroic rocks during seafloor spreading (Escartin et al., 2003;

734 Schroeder and John, 2004; Boschi et al., 2006b). Talc in particular may be influential in

735 lubricating and softening mylonitic shear zones and can lead to strain localization and focused

736 hydrothermal circulation along such faults (see also McCaig et al, 2010). In fact, low-T

737 detachment strain $\left(<\sim 300^{\circ} \mathrm{C}\right)$ may actually be concentrated with time in the weak, talc-

738 serpentine-rich rocks, creating a runaway system and allowing movement on the detachment

739 fault zone to remain active while leaving a large portion of the exposed lithosphere undeformed.

740 In addition, based on detailed studies of greenschist- to amphibolite-facies assemblages in

741 metadolerites in the upper 130m of the IODP Site U1309D drill cores, McCaig and Harris (2012)

742 argue that the detachment fault zone itself acts as a conductive boundary layer between gabbroic

743 intrusions in the footwall and active hydrothermal circulation within the fault zone. They

744 conclude that widespread occurrences of gabbro at high levels in the crust below detachment

745 faults may be an expression of the same fundamental balance between magmatism and

746 hydrothermal circulation that produces a layered structure at fast-spreading ridges.

748 Although alteration in the IODP drill cores is dominated by earlier phases of serpentinization and 749 metasomatism associated with detachment faulting and denudation of mantle peridotites, wide750 scale, active serpentinization at Atlantis Massif is indicated by elevated concentrations of $\mathrm{H}_{2}$ and $751 \mathrm{CH}_{4}$ in bottom water sampled before and after drilling. Even at the transform fault, $\mathrm{H}_{2}$ 
752 concentrations in CTD casts were elevated $(6.2 \mathrm{nM})$ relative to background seawater $(<0.3 \mathrm{nM})$.

753 Monitoring of the borehole fluids during drilling operations recorded numerous excursions in

754 methane, temperature and ORP that often correlated with each other. The fact that the excursions

755 occurred both while drilling as well as when no coring operations were taking place implies that

756 horizons of reduced, and likely hydrogen-rich, fluids must exist in the basement rocks and that

757 volatiles are being continuously expelled during active serpentinization at the Atlantis Massif.

758 Active volatile expulsion was also indicated as bubbles emitting from Site M0070. The diffuse

759 fluid flow indicated by the sensor package data and water sampling during IODP Expedition 357

760 contrasts strongly with the focused flow associated with the actively venting Lost City

761 hydrothermal field. The detachment fault zone seems to play a passive role in channelling the

762 basement fluids. Instead, present-day hydrothermal fluid flow is likely controlled by late-stage

763 normal faults cutting the southern wall (Fig. 1; see also Denny et al., 2015). In addition, the

764 present-day hydrothermal fluids, characterized by high $\mathrm{pH}$, low $\mathrm{Si}$, and low metal concentrations

765 are controlled by serpentinization reactions and are chemically distinct from the higher

766 temperature fluids that were involved with mass transfer and metasomatism at deeper levels of

767 the detachment fault zone and at earlier stages in the evolution of the Atlantis Massif.

769 A major achievement of IODP Expedition 357 was to obtain microbiological samples along the

770 west-east lithospheric age profile, which will provide a better understanding of how microbial

771 communities evolve as ultramafic rocks are emplaced on the seafloor. Our results indicate that

772 the subsurface of the serpentinite basement of Atlantis Massif has relatively low biomass. We

773 anticipate that on-going post-cruise microbiological studies will provide important constraints to

774 address basic questions, such as what is the nature of microbial communities hosted by 
775 serpentinizing rocks, and to what depth is microbial activity sustained? How do these vary with

776 aging of the lithosphere? How do they differ from or interact with communities in sediments and

777 mafic substrates in the same age crust? Because of the significant difference in volatile

778 compositions and limited $\mathrm{CO}_{2}$ stability at high $\mathrm{pH}$, one can expect that biotopes hosted in

779 serpentinizing environments will differ significantly from axial, basaltic-hosted vent systems in

780 which $\mathrm{CO}_{2}$ is a dominant volatile species. In addition, the mixing of oxidized seawater with

781 highly reduced fluids leads to complex gradients in fluid chemistry and possibly temperature that

782 may influence microbial distribution and activity. Substantially different habitats harboring

783 various types of aerobic and anaerobic metabolisms may thus occur over a narrow spatial scale

784 in these types of environments.

785

786 Acknowledgements

788 We thank the captain and crew aboard the RRS James Cook and the ESO staff for their efforts

789 and support during all phases of IODP Expedition 357. Funding by ECORD is gratefully

790 acknowledged and each of the IODP Exp. 357 participants thanks their representative national

791 funding agencies for IODP support to participate in the expedition and conduct post-cruise

792 studies. This contribution was greatly improved by the thoughtful and thorough reviews from an

793 anonymous reviewer and Nicholas Haymon.

794

795 Supplementary Material

796 Appendix A. Synthesis of the lithological contacts, mineralogies and off shore analyses of the 797 western Hole M0071A (IODP Expedition 357). 
799 Appendix B. Synthesis of the lithological contacts, mineralogies and off shore analyses of the 800 western Hole M0071B (IODP Expedition 357).

801

802 Appendix C. Synthesis of the lithological contacts, mineralogies and off shore analyses of the 803 western Hole M0071C (IODP Expedition 357).

804

805 Appendix D. Synthesis of the lithological contacts, mineralogies and off shore analyses of the 806 central Hole M0069A (IODP Expedition 357).

807

808 Appendix E. Synthesis of the lithological contacts, mineralogies and off shore analyses of the 809 central Hole M0072B, IODP Expedition 357 (Part 1).

810

811 Appendix F. Synthesis of the lithological contacts, mineralogies and off shore analyses of the 812 central Hole M0072B, IODP Expedition 357 (Part 2).

813

814 Appendix G. Synthesis of the lithological contacts, mineralogies and off shore analyses of the 815 central Hole M0076B, IODP Expedition 357 (Part 1).

816

817 Appendix H. Synthesis of the lithological contacts, mineralogies and off shore analyses of the 818 central Hole M0076B, IODP Expedition 357 (Part 2). 
820 Appendix I. Synthesis of the lithological contacts, mineralogies and off shore analyses of eastern $821 \quad$ Hole M0068B (IODP Expedition 357).

822

823 Appendix J. Synthesis of the lithological contacts, mineralogies and off shore analyses of eastern 824 Hole M0075B (IODP Expedition 357).

825

826

827

828

829

830

\section{References}

Alt, J.C., Shanks, W.C., III, 2003. Serpentinization of abyssal peridotites from the MARK area, Mid-Atlantic Ridge: sulfur geochemistry and reaction modeling. Geochimica et Cosmochimica Acta 67(4), 641-653.

831 Andreani, M., Mével, C., Boullier, A.-M., Escartin, J., 2007. Dynamic control on serpentine

832 crystallization in veins: constraints on hydration processes in oceanic peridotites. Geochemistry, 833 Geophysics, Geosystems 8(2), Q02012.

834 Blackman, D.K., Karson, J.A., Kelley, D.S., Cann, J.R., Früh-Green, G.L., Gee, J.S., Hurst, S.D., 835 John, B.E. Morgan, J., Nooner, S.L., Ross, D.K., Schroeder, T.J., Williams, E.A., 2002.

836 Geology of the Atlantis Massif (Mid-Atlantic Ridge, $30^{\circ} \mathrm{N}$ ): implications for the evolution of an 837 ultramafic oceanic core complex. Marine Geophysical Research 23(5-6), 443-469.

838 Blackman, D.K., Ildefonse, B., John, B.E., Ohara, Y., Miller, D.J., MacLeod, C.J., the Expedition 839 304/305 Scientists, 2016. Proceedings of the Integrated Ocean Drilling Program, Volume 840 304/305: College Station, TX, Integrated Ocean Drilling Program Management International, $841 \quad$ Inc., doi: 10.2204/iodp. proc.304305.2006. 
Boschi, C., Früh-Green, G.L., Delacour, A., Karson, J.A., Kelley, D.S., 2006a. Mass transfer and fluid flow during detachment faulting and development of an oceanic core complex, Atlantis Massif (MAR 30N). Geochemistry, Geophysics, Geosystems 7(1), Q01004.

Boschi, C., Früh-Green, G.L., Escartin, J., 2006b. Occurrence and significance of serpentinitehosted, talc-rich fault rocks in modern oceanic settings and ophiolite complexes. Ofioliti 31(2), 123-134.

Boschi, C., Dini, A., Früh-Green, G.L., Kelley, D.S., 2008. Isotopic and element exchange during serpentinization and metasomatism at the Atlantis Massif (MAR $\left.30^{\circ} \mathrm{N}\right)$ : insights from $\mathrm{B}$ and $\mathrm{Sr}$ isotopes. Geochimica et Cosmochimica Acta 72(7), 1801-1823.

Brazelton, W.J., Baross, J.A., 2009. Abundant transposases encoded by the metagenome of a hydrothermal chimney biofilm. ISME Journal 3(12), 1420-1424.

Brazelton, W.J., Schrenk, M.O., Kelley, D.S., Baross, J.A., 2006. Methane- and sulfurmetabolizing microbial communities dominate the Lost City hydrothermal field ecosystem. Applied and Environmental Microbiology 72(9), 6257-6270.

Brazelton, W.J., Thornton, C.N., Hyer, A, Twing, K.I., Longino, A.A., Lang, S.Q., Lilley, M.D., Früh-Green, G.L., Schrenk, M.O., 2017. Metagenomic identification of active methanogens and methanotrophs in serpentinite springs of the Voltri Massif, Italy. PeerJ 5:e2945 https://doi.org/10.7717/peerj.2945.

Cann, J.R., Blackman, D.K., Smith, D.K., McAllister, E., Janssen, B., Mello, S., Avgerinos, E., Pascoe, A.R., Escartín, J., 1997, Corrugated slip surfaces formed at ridge-transform intersections on the Mid-Atlantic Ridge Nature 385, 329-332.

Cannat, M., 1993. Emplacement of mantle rocks in the seafloor at mid-ocean ridges. Journal of Geophysical Research: Solid Earth 98(B3), 4163-4172. 
Cannat, M., Sauter, D., Mendel, V., Ruellan, E., Okino, K., Escartin, J., Combier, V., and Baala, M., 2006. Modes of seafloor generation at a melt-poor ultraslow-spreading ridge. Geology 34(7), 605-608.

Chernosky, J. V. J., 1973. An experimental investigation of the serpentine and chlorite group minerals in the system MgO-A12O3 - SiO2 - H2O, Ph.D. thesis, Mass. Inst. of Tech- nol., Cambridge. geochemistry of serpentinites in the Lost City hydrothermal system $\left(30^{\circ} \mathrm{N}, \mathrm{MAR}\right)$. Geochimica et Cosmochimica Acta 72(15), 3681-3702.

\section{Denny, A.R., Kelley, D.S., and Früh-Green, G.L., 2015. Geologic Evolution of the Lost City} Hydrothermal Field: Geochemistry, Geophysics, Geosystems 17, 375-394, doi:10.1002/ 2015 GC005869.

Dick, H.J.B., Tivey, M.A., Tucholke, B.E., 2008. Plutonic foundation of a slow-spreading ridge segment: oceanic core complex at Kane Megamullion, $23^{\circ} 30^{\prime} \mathrm{N}, 45^{\circ} 20^{\prime} \mathrm{W}$. Geochemistry, Geophysics, Geosystems 9(5), Q05014.

Escartín, J., Canales, J. P., 2011. Detachments in oceanic lithosphere: Deformation, magmatism, fluid flow, and ecosystems. Eos, Transactions American Geophysical Union 92(4), 31-31. Escartín, J., Mével, C., MacLeod, C.J., and McCaig, A.M., 2003. Constraints on deformation conditions and the origin of oceanic detachments: the Mid- Atlantic Ridge core complex at 15 ${ }^{\circ} 45^{\prime}$ N. Geochemistry, Geophysics, Geo- systems, 4(8):1067. http://dx.doi.org/10.1029/2002GC000472. 
Escartín, J., Andreani, M., Hirth, G., Evans, B., 2008. Relationships between the microstructural evolution and the rheology of talc at elevated pressures and temperatures. Earth and Planetary Science Letters 268(3-4), 463-475.

Evans, B. W., 2004. The Serpentinite Multisystem Revisited: Chrysotile Is Metastable. International Geology Review, 46(6), 479-506. http://doi.org/10.2747/0020-6814.46.6.479 Boschi, C., Proskurowksi, G., 2003. 30,000 years of hydrothermal activity at the Lost City vent field. Science 301(5632), 495-498.

Früh-Green, G.L., Connolly, J.A.D., Plas, A., Kelley, D.S., Grobéty, B., 2004. Serpentinization of oceanic peridotites: implications for geochemical cycles and biological activity. In Wilcock,

$$
\text { W.S.D., DeLong, E.F., Kelley, D.S., Baross, J.A., Cary, C., The Subseafloor Biosphere at Mid- }
$$$$
\text { Ocean Ridges. Geophysical Monograph 144, 119-136. }
$$

Früh-Green, G.L., Orcutt, B.N., and Green, S., 2015. Expedition 357 Scientific Prospectus: Atlantis Massif Serpentinization and Life. International Ocean Discovery Program.

$$
\text { http://dx.doi.org/10.14379/iodp.sp.357.2015. }
$$

Früh-Green, G.L., Orcutt, B.N., Green, S., Cotterill, C., and the Expedition 357 Scientists, 2016. Expedition 357 Preliminary Report: Atlantis Massif Serpentinization and Life. International Ocean Discovery Program. http://dx.doi.org/10.14379/iodp.pr.357.2016 Früh-Green, G.L., Orcutt, B.N., Green, S.L., Cotterill, C., Morgan, S., Akizawa, N., Bayrakci, G., Behrmann, J.-H., Boschi, C., Brazelton, W.J., Cannat, M., Dunkel, K.G., Escartin, J., Harris, M., Herrero-Bervera, E., Hesse, K., John, B.E., Lang, S.Q., Lilley, M.D., Liu, H.-Q., Mayhew, L.E., McCaig, A.M., Menez, B., Morono, Y., Quéméneur, M., Rouméjon, S., Sandaruwan Ratnayake, A., Schrenk, M.O., Schwarzenbach, E.M., Twing, K.I., Weis, D., 
Whattam, S.A., Williams, M., Zhao, R., 2017a. Expedition 357 summary, in Früh-Green,

G.L., Orcutt, B.N., Green, S.L., Cotterill, C., and the Expedition 357 Scientists, Atlantis

Massif Serpentinization and Life. Proceedings of the International Ocean Discovery Program,

357: College Station, TX. http://dx.doi.org/10.14379/iodp.proc.357.101.2017.

Früh-Green, G.L., Orcutt, B.N., Green, S.L., Cotterill, C., Morgan, S., Akizawa, N., Bayrakci, G., Behrmann, J.-H., Boschi, C., Brazelton, W.J., Cannat, M., Dunkel, K.G., Escartin, J., Harris, M., Herrero-Bervera, E., Hesse, K., John, B.E., Lang, S.Q., Lilley, M.D., Liu, H.-Q., Mayhew, L.E., McCaig, A.M., Menez, B., Morono, Y., Quéméneur, M., Rouméjon, S., Sandaruwan Ratnayake, A., Schrenk, M.O., Schwarzenbach, E.M., Twing, K.I., Weis, D., Whattam, S.A., Williams, M., Zhao, R., 2017b. Expedition 357 methods, in Früh-Green, G.L., Orcutt, B.N., Green, S.L., Cotterill, C., and the Expedition 357 Scientists, Atlantis Massif Serpentinization and Life. Proceedings of the International Ocean Discovery Program, 357: College Station, TX. http://dx.doi.org/10.14379/iodp.proc.357.102.2017. Früh-Green, G.L., Orcutt, B.N., Green, S.L., Cotterill, C., Morgan, S., Akizawa, N., Bayrakci, G., Behrmann, J.-H., Boschi, C., Brazelton, W.J., Cannat, M., Dunkel, K.G., Escartin, J., Harris, M., Herrero-Bervera, E., Hesse, K., John, B.E., Lang, S.Q., Lilley, M.D., Liu, H.-Q., Mayhew, L.E., McCaig, A.M., Menez, B., Morono, Y., Quéméneur, M., Rouméjon, S., Sandaruwan Ratnayake, A., Schrenk, M.O., Schwarzenbach, E.M., Twing, K.I., Weis, D., Whattam, S.A., Williams, M., Zhao, R., 2017c. Eastern sites, in Früh-Green, G.L., Orcutt, B.N., Green, S.L., Cotterill, C., and the Expedition 357 Scientists, Atlantis Massif Serpentinization and Life. Proceedings of the International Ocean Discovery Program, 357: College Station, TX. http://dx.doi.org/10.14379/iodp.proc.357.103.2017. 
Früh-Green, G.L., Orcutt, B.N., Green, S.L., Cotterill, C., Morgan, S., Akizawa, N., Bayrakci,

G., Behrmann, J.-H., Boschi, C., Brazelton, W.J., Cannat, M., Dunkel, K.G., Escartin, J., Harris, M., Herrero-Bervera, E., Hesse, K., John, B.E., Lang, S.Q., Lilley, M.D., Liu, H.-Q., Mayhew, L.E., McCaig, A.M., Menez, B., Morono, Y., Quéméneur, M., Rouméjon, S., Sandaruwan Ratnayake, A., Schrenk, M.O., Schwarzenbach, E.M., Twing, K.I., Weis, D., Whattam, S.A., Williams, M., Zhao, R., 2017d. Central sites, in Früh-Green, G.L., Orcutt, B.N., Green, S.L., Cotterill, C., and the Expedition 357 Scientists, Atlantis Massif Serpentinization and Life. Proceedings of the International Ocean Discovery Program, 357: College Station, TX. http://dx.doi.org/10.14379/iodp.proc.357.104.2017.

Früh-Green, G.L., Orcutt, B.N., Green, S.L., Cotterill, C., Morgan, S., Akizawa, N., Bayrakci, G., Behrmann, J.-H., Boschi, C., Brazelton, W.J., Cannat, M., Dunkel, K.G., Escartin, J., Harris, M., Herrero-Bervera, E., Hesse, K., John, B.E., Lang, S.Q., Lilley, M.D., Liu, H.-Q., Mayhew, L.E., McCaig, A.M., Menez, B., Morono, Y., Quéméneur, M., Rouméjon, S., Sandaruwan Ratnayake, A., Schrenk, M.O., Schwarzenbach, E.M., Twing, K.I., Weis, D., Whattam, S.A., Williams, M., Zhao, R., 2017e. Western sites, in Früh-Green, G.L., Orcutt, B.N., Green, S.L., Cotterill, C., and the Expedition 357 Scientists, Atlantis Massif Serpentinization and Life. Proceedings of the International Ocean Discovery Program, 357: College Station, TX. http://dx.doi.org/10.14379/iodp.proc.357.102.2017. Früh-Green, G.L., Orcutt, B.N., Green, S.L., Cotterill, C., Morgan, S., Akizawa, N., Bayrakci, G., Behrmann, J.-H., Boschi, C., Brazelton, W.J., Cannat, M., Dunkel, K.G., Escartin, J., Harris, M., Herrero-Bervera, E., Hesse, K., John, B.E., Lang, S.Q., Lilley, M.D., Liu, H.-Q., Mayhew, L.E., McCaig, A.M., Menez, B., Morono, Y., Quéméneur, M., Rouméjon, S., Sandaruwan Ratnayake, A., Schrenk, M.O., Schwarzenbach, E.M., Twing, K.I., Weis, D., 
954

955

956

957

958

959

960

961

962

963

964

965

966

967

968

969

970

971

972

973

974

975

976

Whattam, S.A., Williams, M., Zhao, R., 2017f. Northern sites, in Früh-Green, G.L., Orcutt, B.N., Green, S.L., Cotterill, C., and the Expedition 357 Scientists, Atlantis Massif Serpentinization and Life. Proceedings of the International Ocean Discovery Program, 357: College Station, TX.Northern sites. http://dx.doi.org/10.14379/iodp.proc.357.106.2017. Grimes, C.B., John, B.E., Cheadle, M.J., Wooden, J.L., 2008. Protracted construction of gabbroic crust at a slow spreading ridge: constraints from ${ }^{206} \mathrm{~Pb} /{ }^{238} \mathrm{U}$ zircon ages from Atlantis Massif and IODP Hole U1309D (30N, MAR). Geochemistry, Geophysics, Geosystems, 9, Q08012.

Holm, N.G., Charlou, J.L., 2001. Initial indications of abiotic formation of hydrocarbons in the Rainbow ultramafic hydrothermal system, Mid-Atlantic Ridge. Earth and Planetary Science Letters, 191(1-2), 1-8.

Ildefonse, B., Blackman, D.K., John, B.E., Ohara, Y., Miller, D.J., MacLeod, C.J., Integrated Ocean Drilling Program Expeditions 304/305 Science Party, 2007. Oceanic core complexes and crustal accretion at slow-spreading ridges. Geology 35(7), 623-626.

Jagoutz, E., Palme, H., Baddenhausen, H., Blum, K., Cendales, M., Dreibus, G., Spettel, B., Lorenz, V., Vanke, H., 1979. The abundance of major, minor and trace elements in the earth's mantle as derived from primitive ultramafic nodules. Geochimica et Cosmochimica Acta 11 (2), 2031-2050.

John, B. E., Cheadle, M. J., 2010. Deformation and alteration associated with oceanic and continental detachment fault systems; are they similar? Geophysical Monograph 188, 175205.

John, B.E., Cheadle, M.J., Gee, J.S., Grimes, C.B., Morris, A., and Pressling, N., 2009. Data report: spatial and temporal evolution of slow spread oceanic crust—graphic sections of core 
recovered from IODP Hole U1309D, Atlantis Massif, 30 N, MAR (including $\mathrm{Pb} / \mathrm{U}$ zircon geochronology and magnetic remanence data). In Blackman, D.K., Ildefonse, B., John, B.E., Ohara, Y., Miller, D.J., MacLeod, C.J., and the Expedition 304/305 Scientists, Proc. IODP, 304/305: College Station, TX (Integrated Ocean Drilling Program Management International, Inc.). doi:10.2204/iodp.proc.304305.205.2009.

Jørgensen, S.L., Zhao, R , 2016. Microbial Inventory of Deeply Buried Oceanic Crust from a Young Ridge Flank. Frontiers in Microbiology 7:820. doi: 10.3389/fmicb.2016.00820. Karson, J.A., Früh-Green, G.L., Kelley, D.S., Williams, E.A., Yoerger, D.R., Jakuba, M., 2006. Detachment shear zone of the Atlantis Massif core complex, Mid-Atlantic Ridge, $30^{\circ} \mathrm{N}$. Geochemistry, Geophysics, Geosystems 7(6), Q06016.

Kelemen, P. B., Dick, H. J., Quick, J. E., 1992. Formation of harzburgite by pervasive melt/rock reaction in the upper mantle. Nature 358(6388), 635-641.

Kelemen, P.B., Kikawa, E., Miller, D.J., Shipboard Scientific Party, 2007. Leg 209 summary: processes in a 20 -km-thick conductive boundary layer beneath the Mid-Atlantic Ridge, $14^{\circ}-$ $16^{\circ}$ N. In Kelemen, P.B., Kikawa, E., Miller, D.J. (Eds.), Proceedings of the Ocean Drilling Program, Scientific Results, 209: College Station, TX (Ocean Drilling Program), 1-33. Kelley, D.S., Karson, J.A., Blackman, D.K., Früh-Green, G.L., Butterfield, D.A., Lilley, M.D., Olson, E.J., Schrenk, M.O., Roe, K.K., Lebon, G.T., Rivizzigno, P., the AT3-60 Shipboard Party, 2001. An off-axis hydrothermal vent field near the Mid-Atlantic Ridge at $30^{\circ}$ N. Nature 412(6843), 145-149.

Kelley, D.S., Karson, J.A., Früh-Green, G.L., Yoerger, D.R., Shank, T.M., Butterfield, D.A., Hayes, J.M., Schrenk, M.O., Olson, E.J., Proskurowski, G., Jakuba, M., Bradley, A., Larson, B., Ludwig, K., Glickson, D., Buckman, K., Bradley, A.S., Brazelton, W.J., Roe, K., Elend, M.J., 
Delacour, A., Bernasconi, S.M., Lilley, M.D., Baross, J.A., Summons, R.E., Sylva, S.P., 2005.

1001

1002

1003

1004

1005

1006

1007

1008

1009

1010

1011

1012

1013

1014

1015

1016

1017

1018

1019

1020

1021

1022

A serpentinite-hosted ecosystem: the Lost City hydrothermal field. Science 307(5714), 14281434.

Konn, C., Charlou, J.L., Donval, J.P., Holm, N.G., Dehairs, F., Bouillon, S., 2009. Hydrocarbons and oxidized organic compounds in hydrothermal fluids from Rainbow and Lost City ultramafic-hosted vents. Chemical Geology 258(3-4), 299-314.

Lang, S.Q., Butterfield, D.A., Schulte, M., Kelley, D.S., Lilley, M.D., 2010. Elevated concentrations of formate, acetate and dissolved organic carbon found at the Lost City hydrothermal field. Geochimica et Cosmochimica Acta 74(3), 941-952.

Lang, S.Q., Früh-Green, G.L., Bernasconi, S.M., Lilley, M.D., Proskurowski, G., Méhay, S., Butterfield, D.A., 2012. Microbial utilization of abiogenic carbon and hydrogen in a serpentinite-hosted system. Geochimica et Cosmochimica Acta 92, 82-99.

Lang S.Q., Früh-Green G.L., Bernasconi S.M., Brazelton W.J., Schrenk, M.O., and McGonigle, J., 2018. Deeply-sourced formate fuels sulfate reducers but not methanogens at Lost City hydrothermal field. Nature Scientific Reports 8, 755.

Ludwig, K.A., Kelley, D.S., Butterfield, D.A., Nelson, B.K., Früh-Green, G.L., 2006. Formation and evolution of carbonate chimneys at the Lost City hydrothermal field. Geochimica et Cosmochimica Acta 70(14), 3625-3645.

Martin, B. and Fyfe, W.S., 1970. Some experimental and theoretical observations on the kinetics of hydration reactions with par-ticular reference to serpentinization, Chemical Geology 6, 185-195. Mason, .U., Nakagawa, T., Rosner, M., Van Nostrand, J.D., Zhou, J., Maruyama, A., Fisk, M.R., Giovannoni, S.J., 2010. First investigation of the microbiology of the deepest layer of ocean crust. PLoS One 5(11), e15399. 
1023

1024

1025

1026

1027

1028

1029

1030

1031

1032

1033

1034

1035

1036

1037

1038

1039

1040

1041

1042

1043

1044

1045

Malvoisin, B., Brunet, F., Carlut, J., Rouméjon, S. \& Cannat, M., 2012. Serpentinization of oceanic peridotites: 2. Kinetics and processes of San Carlos olivine hydrothermal alteration. Journal of Geophysical Research 117, B04102, doi:10.1029/2011JB008842.

McCaig, A.M., Delacour, A., Fallick, A.E., Castelain, T., Früh-Green G.L., 2010. Fluid circulation and isotopic alteration in and beneath oceanic detachment faults in the Central Atlantic: Implications for the geometry and evolution of high-temperature hydrothermal circulation cells at slow-spreading ridges, In: Diversity of Hydrothermal Systems on Slow Spreading Ocean Ridges, eds PA Rona, CW Devey, J Dyment, BJ Murton, AGU Geophy. Mono. Series 188:207-239.

McCaig, A.M., Harris, M., 2012. Hydrothermal circulation and the dike-gabbro transition in the detachment mode of slow seafloor spreading. Geology 40, 367-370. doi: 10.1130/G32789.1.

McCollom, T.M., 2016. Abiotic methane formation during serpentinization. Proceedings of the National Academy of Sciences 113 (49) 13965-13970; DOI:10.1073/pnas.1611843113.

Méhay, S., Früh-Green, G.L., Lang, S.Q., Bernasconi, S.M., Brazelton, W.J., Schrenk, M.O., Schaeffer, P., Adam, P., 2013. Record of archaeal activity at the serpentinite-hosted Lost City hydrothermal field. Geobiology 11(6), 570-592.

Morono, Y., Inagaki, F., Heuer, V.B., Kubo, Y., Maeda, L., Bowden, S., Cramm, M., Henkel, S., Hirose, T., Homola, K., Hoshino, T., Ijiri, A., Imachi, H., Kamiya, N., Kaneko, M., Lagostina, L., Manners, H., McClelland, H.-L., Metcalfe, K., Okutsu, N., Pan, D., Raudsepp, M.J., Sauvage, J., Schubotz, F., Spivack, A., Tonai, S., Treude, T., Tsang, M.-Y., Viehweger, B., Wang, D.T., Whitaker, E., Yamamoto, Y., and Yang, K., 2017. Expedition 370 methods. In Heuer, V.B., Inagaki, F., Morono, Y., Kubo, Y., Maeda, L., and the Expedition 370 Scientists, Temperature Limit of the Deep Biosphere off Muroto. Proceedings of the International Ocean 
Discovery Program, 370: College Station, TX (International Ocean Discovery Program). https://doi.org/10.14379/iodp.proc.370.102.2017

1048 Nicolas, A., 1986. Structure and petrology of peridotites: Clues to their geodynamic 1049 environment. Reviews of Geophysics 24 (4), 875-895.

1050 Nicolas, A., Prinzhofer, A. (1983) Cumulative or residual origin for the transition zone in 1051 ophiolites: structural evidence. Journal of Petrology 24, 188-206.

1052 Niu, Y., 2004. Bulk-rock major and trace element compositions of abyssal peridotites:

1053 implications for mantle melting, melt extraction and post-melting processes beneath mid$1054 \quad$ ocean ridges. Journal of Petrology 45, 2423-2458.

1055 Orcutt, B.N., Bergenthal, M., Freudenthal, T., Smith, D., Lilley, M.D., Schnieders, L., Green, S., 1056 Früh-Green, G.L., 2017. Contamination tracer testing with seabed drills: IODP Expedition 1057 357. Scientific Drilling 23, 39-46.

1058 Paulick, H., Bach,W., Godard, M., De Hoog, J.C.M., Suhr, G., Harvey, J., 2006. Geochemistry 1059 of abyssal peridotites (Mid-Atlantic Ridge, $15^{\circ} 20^{\prime} \mathrm{N}$, ODP Leg 209): implications for 1060 fluid/rock interaction in slow spreading environments. Chemical Geology 234, 179-210. 1061 Proskurowski, G., Lilley, M.D., Kelley, D.S., Olson, E.J., 2006. Low temperature volatile 1062 production at the Lost City hydrothermal field, evidence from a hydrogen stable isotope 1063 geothermometer. Chemical Geology 229(4), 331-343.

1064 Proskurowski, G., Lilley, M.D., Seewald, J.S., Früh-Green, G.L., Olson, E.J., Lupton, J.E., Sylva, 1065 S.P., Kelley, D.S., 2008. Abiogenic hydrocarbon production at Lost City hydrothermal field. $1066 \quad$ Science 319(5863), 604-607. 
1067 Rouméjon, S., Cannat, M., 2014. Serpentinization of mantle-derived peridotites at mid-ocean 1068 ridges: Mesh texture development in the context of tectonic exhumation. Geochemistry, $1069 \quad$ Geophysics, Geosystems 15, 2354-2379.

1070 Rouméjon, S., Cannat, M., Agrinier, P., Godard, M. \& Andreani, M., 2015. Serpentinization and 1071 Fluid Pathways in Tectonically Exhumed Peridotites from the Southwest Indian Ridge (62-65 1072 E). Journal of Petrology 56, 703-734.

1073 Rouméjon, S., Früh-Green, G.L., Orcutt, B.N., and the IODP Expedition 357 Science Party, 1074 2018. Alteration heterogeneities in peridotites exhumed on the southern wall of the Atlantis 1075 Massif (IODP Expedition 357). Journal of Petrology, 2018, 1-29, doi:

$1076 \quad 10.1093 /$ petrology/egy065.

1077 Rouméjon, S., Williams, M.J., Früh-Green, G.L., this issue. In situ oxygen isotope analyses in 1078 serpentine minerals: constraints on serpentinization during tectonic exhumation at slow- and 1079 ultraslow-spreading ridges.

1080 Schoolmeesters, N., M. J. Cheadle, B. E. John, P. W. Reiners, J. Gee, and C. B. Grimes (2012), 1081 The cooling history and the depth of detachment faulting at the Atlantis Massif oceanic core 1082 complex, Geochemistry, Geophysics, Geosystems 13, Q0AG12, doi:10.1029/2012GC004314. 1083 Schrenk, M.O., Kelley, D.S., Bolton, S.A., Baross, J.A., 2004. Low archaeal diversity linked to 1084 subseafloor geochemical processes at the Lost City hydrothermal field, Mid-Atlantic Ridge. 1085 Environmental Microbiology 6, 1086-1095.

1086 Schrenk, M.O., Brazelton, W.J., Lang, S.Q., 2013. Serpentinization, carbon, and deep life. 1087 Reviews in Mineralogy and Geochemistry 75 (1), 575-606.

1088 Schroeder, T., John, B., Frost, B.R., 2002. Geologic implications of seawater circulation through 1089 peridotite exposed at slow-spreading mid-ocean ridges. Geology 30(4), 367-370. 
1090 Schroeder, T., John, B.E., 2004. Strain localization on an oceanic detachment fault system, 1091 Atlantis Massif, 30 N, Mid-Atlantic Ridge. Geochemistry, Geophysics, Geosystems 5, 1092 Q11007.

1093 Schwarzenbach E.M., Früh-Green G.L., Bernasconi S.M., Alt J.C, Shanks III W.C., Gaggero 1094 Laura Crispini, L. 2012. Sulfur geochemistry of peridotite-hosted hydrothermal systems: 1095 Comparing the Ligurian ophiolites with oceanic serpentinites. Geochimica Cosmochimica 1096 Acta 91, 283-305.

1097 Smith, D.K., Cann, J.R., Escartin, J., 2006. Widespread active detachment faulting and core 1098 complex formation near $13^{\circ} \mathrm{N}$ on the Mid-Atlantic Ridge. Nature 442(7101), 440-443. 1099 Smith, D.K., Escartín, J., Schouten, H., Cann, J.R., 2008. Fault rotation and core complex 1100 formation: significant processes in seafloor formation at slow-spreading mid-ocean ridges (Mid1101 Atlantic Ridge, $13^{\circ}-15^{\circ}$ N). Geochemistry, Geophysics, Geosystems 9(3), Q03003.

1102 Tucholke, B.E., Behn, M.D., Buck, W.R., Lin, J., 2008. Role of melt supply in oceanic detachment 1103 faulting and formation of megamullions. Geology 36(6), 455-458.

1104 1105 
Table 1. IODP Expedition 357 site locations, core recovery, and maximum volatile concentrations.

\begin{tabular}{|c|c|c|c|c|c|c|c|c|c|c|c|c|}
\hline Hole & Latitude & Longitude & $\begin{array}{c}\text { Water depth } \\
(\mathrm{m})\end{array}$ & Drill & $\begin{array}{c}\text { Number of } \\
\text { cores }\end{array}$ & $\begin{array}{l}\text { Interval } \\
\text { cored }(\mathrm{m})\end{array}$ & $\begin{array}{c}\text { Core } \\
\text { recovered } \\
(\mathrm{m})\end{array}$ & $\begin{array}{c}\text { Core } \\
\text { recovery (\%) }\end{array}$ & $\begin{array}{c}\text { Interval } \\
\text { open-holed } \\
(\mathrm{m})\end{array}$ & $\begin{array}{l}\text { Penetration } \\
\text { depth (mbsf) }\end{array}$ & $\begin{array}{c}\text { Maximum } \\
\text { hydrogen } \\
(\mathrm{nM})^{*}\end{array}$ & $\begin{array}{l}\text { Maximum } \\
\text { methane } \\
(\mathrm{nM})^{*}\end{array}$ \\
\hline \multicolumn{13}{|c|}{ Eastern Sites } \\
\hline M0068A & $30^{\circ} 7.49^{\prime} \mathrm{N}$ & $42^{\circ} 5.74^{\prime} \mathrm{W}$ & 1102.7 & $\mathrm{RD} 2$ & 1 & 1.97 & 0.47 & 23.9 & 0 & 1.97 & 34 & BDL \\
\hline M0068B & $30^{\circ} 7.51^{\prime} \mathrm{N}$ & $42^{\circ} 5.75^{\prime} \mathrm{W}$ & 1102 & RD2 & 9 & 9.6 & 6.34 & 66.04 & 0 & 9.6 & 137 & $\mathrm{BDL}$ \\
\hline M0075A & $30^{\circ} 7.67^{\prime} \mathrm{N}$ & $42^{\circ} 3.98^{\prime} \mathrm{W}$ & 1568 & RD2 & 1 & 1.72 & 0.65 & 37.79 & 0 & 1.72 & 3 & $\mathrm{BDL}$ \\
\hline M0075B & $30^{\circ} 7.65^{\prime} \mathrm{N}$ & $42^{\circ} 3.97^{\prime} \mathrm{W}$ & 1568 & RD2 & 3 & 5.7 & 2.73 & 47.88 & 0 & 5.7 & & $\mathrm{BDL}$ \\
\hline \multicolumn{13}{|c|}{ Central Sites } \\
\hline M0069A & $30^{\circ} 7.94^{\prime} \mathrm{N}$ & $42^{\circ} 7.20^{\prime} \mathrm{W}$ & 850.9 & $\mathrm{RD} 2$ & 10 & 16.44 & 12.29 & 75 & 0 & 16.44 & 58 & 4 \\
\hline M0072A & $30^{\circ} 7.79^{\prime} \mathrm{N}$ & $42^{\circ} 7.32^{\prime} \mathrm{W}$ & 820.3 & RD2 & 2 & 2.23 & 0.87 & 39.1 & 0 & 2.23 & 12 & 2 \\
\hline M0072B & $30^{\circ} 7.79^{\prime} \mathrm{N}$ & $42^{\circ} 7.32^{\prime} \mathrm{W}$ & 820.3 & RD2 & 8 & 11.61 & 6.49 & 52.3 & 0.825 & 12.43 & 323 & 2 \\
\hline M0076A & $30^{\circ} 7.62^{\prime} \mathrm{N}$ & $42^{\circ} 7.08^{\prime} \mathrm{W}$ & 768 & RD2 & 1 & 1.72 & 0.4 & 23.26 & 0 & 1.72 & - & - \\
\hline M0076B & $30^{\circ} 7.62^{\prime} \mathrm{N}$ & $42^{\circ} 7.07^{\prime} \mathrm{W}$ & 768 & RD2 & 10 & 16.31 & 11.71 & 71.8 & 0 & 16.31 & 12 & 3 \\
\hline \multicolumn{13}{|c|}{ Western Sites } \\
\hline M0071A & $30^{\circ} 7.71^{\prime} \mathrm{N}$ & $42^{\circ} 9.20^{\prime} \mathrm{W}$ & 1390.8 & MeBo & 2 & 5.22 & 2.85 & 54.6 & 0 & 5.22 & 61 & BDL \\
\hline M0071B & $30^{\circ} 7.72^{\prime} \mathrm{N}$ & $42^{\circ} 9.19^{\prime} \mathrm{W}$ & 1380 & RD2 & 3 & 4.3 & 2.31 & 53.62 & 0 & 4.3 & 8 & $\mathrm{BDL}$ \\
\hline M0071C & $30^{\circ} 7.70^{\prime} \mathrm{N}$ & $42^{\circ} 9.21^{\prime} \mathrm{W}$ & 1390 & MeBo & 9 & 12.15 & 4.44 & 30.29 & 0 & 12.15 & 6 & $\mathrm{BDL}$ \\
\hline M0073A & $30^{\circ} 7.90^{\prime} \mathrm{N}$ & $42^{\circ} 10.97^{\prime} \mathrm{W}$ & 1430.2 & MeBo & 1 & 2.2 & 0 & 0 & 0 & 2.2 & 40 & $B D L$ \\
\hline \multicolumn{13}{|c|}{ Northern Sites } \\
\hline M0070A & $30^{\circ} 8.55^{\prime} \mathrm{N}$ & $42^{\circ} 8.19^{\prime} \mathrm{W}$ & 1140.5 & MeBo & 3 & 4 & 2.09 & 52.25 & 0 & 4 & 73 & 2 \\
\hline M0070B & $30^{\circ} 8.54^{\prime} \mathrm{N}$ & $42^{\circ} 8.16^{\prime} \mathrm{W}$ & 1140.5 & RD2 & 1 & 1.3 & 0.38 & 29.23 & 0 & 1.3 & 5 & 5 \\
\hline M0070C & $30^{\circ} 8.54^{\prime} \mathrm{N}$ & $42^{\circ} 8.19^{\prime} \mathrm{W}$ & 1140.5 & MeBo & 3 & 5.21 & 2.21 & 42.42 & 0 & 5.21 & - & - \\
\hline M0074A & $30^{\circ} 9.87^{\prime} \mathrm{N}$ & $42^{\circ} 7.32^{\prime} \mathrm{W}$ & 1550 & MeBo & 1 & 2.68 & 0.86 & 32.09 & 0 & 2.68 & BDL & BDL \\
\hline
\end{tabular}

Notes: * Maximum dissolved concentrations in waters sampled after drilling. Full data set of hydrogen and methane concentrations in Früh-Green et al., 2017c. http://publications.iodp.org/proceedings/357/EXP_REPT/TABLES/357_103/357_103_T12.CSV

$\mathrm{BDL}=$ Below detection limited 
Table 2. Bulk rock chemical compositions of representative lithologies from IODP Exp. 357

\begin{tabular}{|c|c|c|c|c|c|c|c|c|c|c|c|c|c|c|c|c|c|c|c|}
\hline $\begin{array}{l}\text { Hole } \\
\text { Core } \\
\text { Cm } \\
68\end{array}$ & $\begin{array}{l}\text { M0071A } \\
1 \mathrm{R}-2 \\
120-121\end{array}$ & $\begin{array}{l}\text { M0071A } \\
\text { 2R-1 } \\
64-67\end{array}$ & $\begin{array}{l}\text { Mo071C } \\
\text { 1R-1 } \\
11-13\end{array}$ & $\begin{array}{l}\text { M0071C } \\
\text { 2R-1 } \\
74-76\end{array}$ & $\begin{array}{l}\text { M0069A } \\
5 \mathrm{R}-1 \\
29.5-32\end{array}$ & $\begin{array}{l}\text { M0069A } \\
\text { 5R-1 } \\
110-113\end{array}$ & $\begin{array}{l}\text { M0069A } \\
10 R-1 \\
80-87\end{array}$ & $\begin{array}{l}\text { M0069A } \\
10 R-3 \\
0-2.5\end{array}$ & $\begin{array}{l}\text { M0072B } \\
5 R-1 \\
37-38\end{array}$ & $\begin{array}{l}\text { M0072B } \\
7 \mathrm{R}-1 \\
72.5-75\end{array}$ & $\begin{array}{l}\text { M0072B } \\
8 \mathrm{R}-1 \\
34-38\end{array}$ & $\begin{array}{l}\text { M0072B } \\
8 \mathrm{R}-2 \mathrm{~B} \\
76-77\end{array}$ & $\begin{array}{l}\text { M0076B } \\
\text { 7R-1 } \\
81-83\end{array}$ & $\begin{array}{l}\text { M00688A } \\
\text { 1R-1 } \\
34-35\end{array}$ & $\begin{array}{l}\text { M0068B } \\
1 \mathrm{R}-1 \\
37.5-40\end{array}$ & $\begin{array}{l}\text { M0068B } \\
\text { IR-1 } \\
134-139\end{array}$ & $\begin{array}{l}\text { M0068B } \\
\text { 2R-1 } \\
31-36\end{array}$ & $\begin{array}{l}\text { M0068B } \\
2-18 \\
52-55\end{array}$ & $\begin{array}{c}\text { M0075B } \\
2 R-1 \\
66-\end{array}$ \\
\hline Top depth & 1.780 & 3.360 & 0.110 & 3.420 & 7.175 & 7.980 & 15.520 & 16.290 & 6.355 & 9.713 & 11.048 & 12.268 & 10.534 & 0.340 & 0.375 & 1.340 & 2.030 & 2.240 & 2.940 \\
\hline \multirow{2}{*}{$\begin{array}{l}\text { Botom depth } \\
\text { Rock type }\end{array}$} & $\begin{array}{l}1.1900 \\
\text { Serp }\end{array}$ & 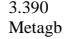 & 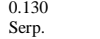 & $\begin{array}{l}\text { 3.440 } \\
\text { Serp }\end{array}$ & $\begin{array}{r}7.200 \\
\text { Metadol }\end{array}$ & $\begin{array}{l}8.010 \\
\text { Metadol }\end{array}$ & $\begin{array}{l}15.590 \\
\text { Serp }\end{array}$ & $\begin{array}{l}16.315 \\
\text { Serp }\end{array}$ & $\begin{array}{l}6.365 \\
\text { Tale schist }\end{array}$ & $\begin{array}{l}9.738 \\
\text { Metasom }\end{array}$ & $\begin{array}{l}11.088 \\
\text { Metasom }\end{array}$ & $\begin{array}{l}12.278 \\
\text { Metasom }\end{array}$ & $\begin{array}{l}10.554 \\
\text { Serp }\end{array}$ & $\begin{array}{l}0.350 \\
\text { Tals schist }\end{array}$ & $\begin{array}{l}0.400 \\
\text { Serp }\end{array}$ & $\begin{array}{l}1.3900 \\
\text { Gabbro }\end{array}$ & $\begin{array}{l}2.080 \\
\text { Gabbro }\end{array}$ & $\begin{array}{l}2.270 \\
\text { Talc schist }\end{array}$ & 2.960 \\
\hline & $\begin{array}{l}\text { Metadol } \\
\text { Dunite }\end{array}$ & & Harzburgite & Harzburgite & & Harzburgite & Dunite & & Harzburgite & Harzburgite & Harzburgite & Harzburgite & & Harzburgite & & & & & \\
\hline \multicolumn{20}{|c|}{ Major elements (wt.\%) } \\
\hline $\mathrm{SiO}_{2}$ & 36.62 & 26.21 & 37.75 & 39.95 & 26.31 & 31.61 & 36.19 & 33.08 & 50.64 & 42.41 & 38.60 & 43.53 & 39.55 & 50.01 & 40.03 & 52.14 & 50.77 & 59.63 & 47.09 \\
\hline $\begin{array}{l}\mathrm{TiO}_{2} \\
\mathrm{Al}_{2} \mathbf{O}_{3}\end{array}$ & 0.02 & 0.24 & 0.02 & 0.05 & 0.92 & ${ }_{20.40}^{1.40}-\mathrm{C}=$ & $\begin{array}{l}0.03 \\
102\end{array}$ & $\begin{array}{l}0.03 \\
158\end{array}$ & 0.14 & 0.03 & 0.03 & $\begin{array}{l}0.05 \\
1.86\end{array}$ & 0.03 & $\begin{array}{l}0.10 \\
4.27\end{array}$ & 0.03 & 0.43 & 0.30 & 0.02 & 1.08 \\
\hline $\begin{array}{l}{ }^{2} l_{2} \mathrm{O}_{3} \\
\mathrm{Fe}_{2} \mathrm{O}_{3}\end{array}$ & $\begin{array}{l}1.11 \\
9.06 \\
-10\end{array}$ & $\begin{array}{l}21.04 \\
32.07\end{array}$ & $\begin{array}{l}1.17 \\
9.19\end{array}$ & $\begin{array}{l}1.27 \\
9.34\end{array}$ & $\begin{array}{l}18.48 \\
27.46\end{array}$ & $\begin{array}{l}20.36 \\
18.75\end{array}$ & $\begin{array}{l}1.02 \\
8.85\end{array}$ & $\begin{array}{l}1.58 \\
10.98\end{array}$ & $\begin{array}{l}3.82 \\
3.35\end{array}$ & $\begin{array}{l}1.05 \\
9.79\end{array}$ & $\begin{array}{l}1.222 \\
9.91 \\
-\end{array}$ & $\begin{array}{l}1.86 \\
6.92\end{array}$ & $\begin{array}{l}0.86 \\
8.24\end{array}$ & $\begin{array}{l}4.27 \\
8.49\end{array}$ & $\begin{array}{l}1.16 \\
9.98\end{array}$ & $\begin{array}{l}16.40 \\
8.30\end{array}$ & $\begin{array}{l}17.753 \\
6.75\end{array}$ & $\begin{array}{l}1.05 \\
6.68\end{array}$ & $\begin{array}{l}18.23 \\
12.09\end{array}$ \\
\hline $\begin{array}{l}\mathrm{MnO} \\
\mathbf{M g O}\end{array}$ & 0.08 & 0.68 & 0.11 & 0.10 & 0.17 & 0.16 & 0.08 & 0.07 & 0.06 & 0.09 & 0.09 & 0.13 & 0.20 & 0.14 & 0.11 & 0.15 & 0.13 & 0.14 & 0.12 \\
\hline $\begin{array}{l}\mathrm{MgO} \\
\mathrm{CaO}\end{array}$ & $\begin{array}{l}40.05 \\
0.09\end{array}$ & $\begin{array}{l}14.19 \\
0.40\end{array}$ & 39.58 & 39.49 & $\begin{array}{l}16.68 \\
106\end{array}$ & $\begin{array}{l}17.41 \\
3.58\end{array}$ & $\begin{array}{l}37.71 \\
1.75\end{array}$ & $\begin{array}{l}39.22 \\
0.18\end{array}$ & $\begin{array}{l}26.06 \\
7.66\end{array}$ & $\begin{array}{l}37.03 \\
0.72\end{array}$ & $\begin{array}{l}37.61 \\
0.45\end{array}$ & $\begin{array}{l}33.18 \\
2.26\end{array}$ & $\begin{array}{l}37.86 \\
1.03\end{array}$ & $\begin{array}{l}22.87 \\
2.64\end{array}$ & 38.78 & 9.25 & 8.98 & $\begin{array}{l}28.14 \\
1.66\end{array}$ & 11.23 \\
\hline $\begin{array}{l}\mathrm{CaO} \\
\mathrm{Na}_{2} \mathrm{O}\end{array}$ & $\begin{array}{l}0.09 \\
0.00\end{array}$ & $\begin{array}{l}0.20 \\
0.28\end{array}$ & $\begin{array}{l}0.10 \\
0.00\end{array}$ & $\begin{array}{l}0.27 \\
0.10\end{array}$ & $\begin{array}{l}1.06 \\
0.14\end{array}$ & $\begin{array}{l}3.58 \\
0.66\end{array}$ & $\begin{array}{l}1.13 \\
0.09\end{array}$ & $\begin{array}{l}0.18 \\
0.00\end{array}$ & $\begin{array}{l}. .66 \\
0.21\end{array}$ & $\begin{array}{l}0.12 \\
0.15\end{array}$ & $\begin{array}{l}0.45 \\
0.09\end{array}$ & $\begin{array}{l}2.26 \\
0.35\end{array}$ & 0.14 & $\begin{array}{l}2.64 \\
0.26\end{array}$ & 0.15 & $\begin{array}{l}11.82 \\
2.82\end{array}$ & 2.75 & $\begin{array}{l}1.66 \\
0.22\end{array}$ & $\begin{array}{l}1.90 \\
1.88\end{array}$ \\
\hline $\begin{array}{l}\mathrm{K}_{2} \mathrm{O} \\
\mathrm{P}_{0}\end{array}$ & 0.00 & 0.03 & 0.00 & 0.05 & 0.00 & 0.02 & 0.00 & 0.00 & 0.00 & 0.00 & 0.00 & 0.00 & 0.01 & 0.00 & 0.05 & 0.00 & 0.00 & 0.02 & 0.00 \\
\hline $\begin{array}{l}\mathbf{P}_{2} \mathbf{O}_{5} \\
\text { LOI }\end{array}$ & 0.01 & 0.02 & 0.02 & & 0.06 & 0.12 & $\begin{array}{l}0.00 \\
1.58\end{array}$ & 0.01 & 0.02 & 0.01 & 0.00 & 0.01 & 0.02 & 0.04 & 0.00 & 0.04 & 0.01 & 0.01 & 0.07 \\
\hline TOTAL & $\begin{array}{l}12.10 \\
99.14 \\
103.02\end{array}$ & $\begin{array}{l}8.49 .63 \\
103.63\end{array}$ & $\begin{array}{l}11.72 \\
99.76\end{array}$ & $\begin{array}{l}\text { L2.06 } \\
102.70\end{array}$ & $\begin{array}{l}8.31 \\
99.59\end{array}$ & $\begin{array}{l}7.86 \\
101.92\end{array}$ & $\begin{array}{l}13.58 \\
99.29\end{array}$ & $\begin{array}{l}13.81 \\
98.95\end{array}$ & $\begin{array}{l}4.73 \\
96.70\end{array}$ & $\begin{array}{l}10.82 \\
102.10\end{array}$ & $\begin{array}{l}12.38 \\
100.38\end{array}$ & $\begin{array}{l}10.27 \\
98.55\end{array}$ & $\begin{array}{l}12.97 \\
100.91\end{array}$ & $\begin{array}{l}5.34 \\
94.16\end{array}$ & $\begin{array}{l}11.95 \\
102.47\end{array}$ & $\begin{array}{l}0.41 \\
101.57\end{array}$ & $\begin{array}{l}0.30 \\
98.80\end{array}$ & $\begin{array}{l}4.30 \\
101.86\end{array}$ & 3.33 \\
\hline Mg\# & 90 & 47 & 90 & & 55 & 65 & 89 & 88 & 94 & 88 & 88 & 90 & 90 & 84 & 89 & 69 & 73 & 89 & \\
\hline $\mathrm{MgO} / \mathrm{SiO}_{2}$ & 1.09 & $\begin{array}{l}0.54 \\
0.7\end{array}$ & $\begin{array}{l}105 \\
105\end{array}$ & 0 & 0.63 & 0.55 & 104 & $\begin{array}{l}01 \\
1.19\end{array}$ & 0.51 & $\begin{array}{l}0.87 \\
0.87\end{array}$ & $\begin{array}{l}0.97 \\
0.97\end{array}$ & 0.76 & ${ }_{0.96}^{O}$ & 0.46 & 0.97 & 0.18 & 0.18 & $\begin{array}{l}8.47 \\
0.79\end{array}$ & 024 \\
\hline $\mathrm{Al}_{2} \mathrm{O}_{3} / \mathrm{SiO}_{2}$ & 0.03 & 0.80 & 0.03 & 0.03 & 0.70 & 0.64 & 0.03 & 0.05 & 0.08 & 0.02 & 0.03 & 0.04 & 0.02 & 0.09 & 0.03 & 0.31 & 0.35 & 0.02 & 0.39 \\
\hline \multicolumn{20}{|c|}{ Trace elements (ppm) } \\
\hline $\begin{array}{c}\mathrm{Cr} \\
\mathrm{Ni}\end{array}$ & $\begin{array}{l}21572 \\
1450\end{array}$ & 748 & $\begin{array}{l}11705 \\
6715\end{array}$ & 3796 & 680 & 523 & 8363 & 29698 & $\begin{array}{l}1986 \\
1053\end{array}$ & $\begin{array}{l}2746 \\
367\end{array}$ & 3614 & 2663 & 2420 & 1349 & 3079 & 100 & 142 & 1746 & 414 \\
\hline Li & $\begin{array}{l}149.74 \\
22.74\end{array}$ & $\begin{array}{l}190.60 \\
16.60\end{array}$ & $\begin{array}{l}6 / 13 \\
12.95\end{array}$ & 3.93 & $\begin{array}{l}341 \\
6.76\end{array}$ & $\begin{array}{l}436 \\
12.76\end{array}$ & $\begin{array}{l}6531 \\
2.59\end{array}$ & $\begin{array}{l}9931 \\
0.22\end{array}$ & $\begin{array}{l}1233 \\
0.15\end{array}$ & $\begin{array}{l}3.481 \\
1.47\end{array}$ & $\begin{array}{l}2193 \\
0.49\end{array}$ & $\begin{array}{l}1984 \\
1.94\end{array}$ & $\begin{array}{l}2810 \\
8.73\end{array}$ & $\begin{array}{l}1640 \\
13.12\end{array}$ & $\begin{array}{l}1051 \\
6.29\end{array}$ & $\begin{array}{l}91.65 \\
5.65\end{array}$ & $\begin{array}{l}94.39 \\
4.39\end{array}$ & $\begin{array}{l}21.67 \\
21.67\end{array}$ & $\begin{array}{l}226 \\
12.48\end{array}$ \\
\hline $\begin{array}{l}\text { Sc } \\
\mathbf{y}\end{array}$ & $\begin{array}{l}82.79 \\
340\end{array}$ & $\begin{array}{l}41.08 \\
139\end{array}$ & $\begin{array}{l}30.04 \\
190\end{array}$ & ${ }_{74}^{16.53}$ & $\begin{array}{l}37.40 \\
198\end{array}$ & ${ }_{202}^{41.16}$ & $\begin{array}{l}29.24 \\
85\end{array}$ & $\begin{array}{l}14.31 \\
116\end{array}$ & $\begin{array}{l}17.68 \\
60\end{array}$ & $\begin{array}{l}9.71 \\
28\end{array}$ & 6.60 & 8.35 & 7.95 & 7.91 & 10.37 & 41.62 & 35.61 & $\begin{array}{l}7.56 \\
10\end{array}$ & $\begin{array}{l}35.90 \\
110\end{array}$ \\
\hline co & $\begin{array}{l}340 \\
622\end{array}$ & $\begin{array}{l}139 \\
152\end{array}$ & $\begin{array}{l}190 \\
315\end{array}$ & $\begin{array}{l}74 \\
137\end{array}$ & $\begin{array}{l}198 \\
191\end{array}$ & $\begin{array}{l}292 \\
149\end{array}$ & $\begin{array}{l}83 \\
282\end{array}$ & $\begin{array}{l}116 \\
408\end{array}$ & $\begin{array}{l}60 \\
33\end{array}$ & ${ }_{155}^{28}$ & ${ }_{101}^{26}$ & ${ }_{77}^{32}$ & $\begin{array}{l}34 \\
116\end{array}$ & 78 & $\begin{array}{l}42 \\
95\end{array}$ & $\begin{array}{l}190 \\
38\end{array}$ & 35 & $\begin{array}{l}19 \\
56\end{array}$ & $\begin{array}{l}179 \\
53\end{array}$ \\
\hline $\mathrm{Cu}$ & 120 & 0 & 231 & 16 & 0 & 1 & 5 & 14 & 3 & 1 & 0 & 1 & 4 & $\begin{array}{l}18 \\
18\end{array}$ & 24 & 49 & 44 & 18 & 2 \\
\hline $\mathrm{Zn}$ & 318 & 331 & 395 & 64 & 44 & 38 & 88 & 255 & 7 & 21 & 21 & 16 & 24 & 73 & 57 & 48 & 39 & $\begin{array}{l}10 \\
87\end{array}$ & 24 \\
\hline Ga & 9.62 & 10.49 & 5.55 & 1.58 & & 23.42 & 2.96 & 7.10 & 5.56 & 2.13 & 1.74 & 3.17 & 1.23 & 7.34 & 1.21 & 14.86 & 14.46 & 2.03 & 17.29 \\
\hline & 0.20 & 0.16 & 0.10 & 0.03 & 0.07 & 0.13 & 0.00 & 0.00 & 0.00 & 0.10 & 0.05 & 0.31 & 0.07 & 0.11 & 0.13 & 0.36 & 0.16 & 0.11 & 0.27 \\
\hline $\begin{array}{l}\text { Sr } \\
Y \text { r }\end{array}$ & $\begin{array}{l}17.24 \\
2.33\end{array}$ & $\begin{array}{l}3.01 \\
6.88\end{array}$ & $\begin{array}{l}10.09 \\
0.99\end{array}$ & $\begin{array}{l}3.06 \\
0.38\end{array}$ & $\begin{array}{l}1.73 \\
22.71\end{array}$ & $\begin{array}{l}57.97 \\
31.68\end{array}$ & $\begin{array}{l}757.58 \\
2.18\end{array}$ & $\begin{array}{l}3.61 \\
0.09\end{array}$ & $\begin{array}{l}2.72 \\
7.75\end{array}$ & $\begin{array}{l}2.13 \\
3.54\end{array}$ & $\begin{array}{l}1.02 \\
1.84\end{array}$ & $\begin{array}{l}3.01 \\
7.12\end{array}$ & $\begin{array}{l}13.60 \\
2.12\end{array}$ & $\begin{array}{l}3.96 \\
41.57\end{array}$ & $\begin{array}{l}3.29 \\
1.29\end{array}$ & $\begin{array}{l}81.98 \\
1484\end{array}$ & $\begin{array}{l}84.97 \\
8.08\end{array}$ & 2.36 & $\begin{array}{l}72.47 \\
2257\end{array}$ \\
\hline $\mathrm{Zr}$ & $\begin{array}{l}2.33 \\
0.00\end{array}$ & $\begin{array}{l}6.88 \\
3.13\end{array}$ & $\begin{array}{l}0.99 \\
0.00\end{array}$ & $\begin{array}{l}0.38 \\
0.09\end{array}$ & $\begin{array}{l}22.71 \\
23.45\end{array}$ & $\begin{array}{l}31.68 \\
20.82\end{array}$ & $\begin{array}{l}2.18 \\
1.23\end{array}$ & $\begin{array}{l}0.099 \\
0.00\end{array}$ & $\begin{array}{l}7.15 \\
4.11\end{array}$ & $\begin{array}{l}3.54 \\
1.54\end{array}$ & $\begin{array}{l}1.84 \\
1.17\end{array}$ & $\begin{array}{l}7.12 \\
5.11\end{array}$ & $\begin{array}{l}2.12 \\
0.38\end{array}$ & $\begin{array}{l}41.57 \\
5.43\end{array}$ & $\begin{array}{l}1.03 \\
0.33\end{array}$ & $\begin{array}{l}14.84 \\
17.45\end{array}$ & $\begin{array}{l}8.08 \\
4.76\end{array}$ & $\begin{array}{l}.045 \\
0.41\end{array}$ & $\begin{array}{l}27.57 \\
33.78\end{array}$ \\
\hline $\mathbf{N b}$ & $\begin{array}{l}0.00 \\
0.11\end{array}$ & $\begin{array}{l}3.13 \\
0.02\end{array}$ & $\begin{array}{l}0.00 \\
0.02\end{array}$ & $\begin{array}{l}0.09 \\
0.02\end{array}$ & 0.35 & $\begin{array}{l}20.82 \\
1.56\end{array}$ & $\begin{array}{l}.23 \\
0.05\end{array}$ & $\begin{array}{l}0.00 \\
0.05\end{array}$ & $\begin{array}{l}4.111 \\
0.15\end{array}$ & $\begin{array}{l}.1 .44 \\
0.49\end{array}$ & $\begin{array}{l}1.171 \\
0.47\end{array}$ & $\begin{array}{l}5.11 \\
0.51\end{array}$ & $\begin{array}{l}0.088 \\
0.03\end{array}$ & $\begin{array}{l}\text { S.45 } \\
1.89\end{array}$ & $\begin{array}{l}0.33 \\
0.06\end{array}$ & $\begin{array}{l}11.45 \\
0.30\end{array}$ & $\begin{array}{l}4.16 \\
0.05\end{array}$ & $\begin{array}{l}. .41 \\
0.05\end{array}$ & $\begin{array}{l}39.18 \\
1.24\end{array}$ \\
\hline Mo & 2.18 & 0.22 & 1.04 & 0.27 & 0.21 & 0.14 & 0.62 & 0.37 & 0.01 & 0.21 & 0.18 & 0.21 & 1.30 & 0.46 & 0.40 & 0.16 & 0.20 & 0.15 & 0.18 \\
\hline & 95.23 & 40.86 & 33.98 & 26.71 & 8.63 & 16.64 & 17.48 & 15.49 & 4.10 & 6.83 & 6.43 & 10.01 & 49.11 & 29.42 & 27.48 & 62.06 & 35.36 & 9.30 & 20.17 \\
\hline$S_{S n}$ & 0.05 & 1.71 & 0.20 & 0.08 & 0.55 & 0.81 & 0.20 & 0.14 & 0.22 & 0.23 & 0.28 & 0.53 & 0.10 & $\begin{array}{l}1.28 \\
0.02\end{array}$ & 0.82 & 1.16 & 0.26 & 0.37 & 0.83 \\
\hline $\begin{array}{l}\text { Sb } \\
\text { Ba }\end{array}$ & $\begin{array}{l}1.09 \\
1.19\end{array}$ & $\begin{array}{l}0.02 \\
0.17\end{array}$ & $\begin{array}{l}1.34 \\
0.97\end{array}$ & $\begin{array}{l}0.15 \\
0.30\end{array}$ & $\begin{array}{l}0.01 \\
0.20\end{array}$ & $\begin{array}{l}0.00 \\
1.33\end{array}$ & $\begin{array}{l}0.01 \\
0.72\end{array}$ & $\begin{array}{l}0.01 \\
0.00\end{array}$ & $\begin{array}{l}0.00 \\
0.00\end{array}$ & $\begin{array}{l}0.00 \\
0.00\end{array}$ & $\begin{array}{l}0.00 \\
0.15\end{array}$ & $\begin{array}{l}0.02 \\
0.16\end{array}$ & $\begin{array}{l}0.13 \\
458\end{array}$ & $\begin{array}{l}0.05 \\
0.087\end{array}$ & $\begin{array}{l}0.29 \\
0.88\end{array}$ & $\begin{array}{l}0.03 \\
444\end{array}$ & 0.02 & $\begin{array}{l}0.03 \\
0.23\end{array}$ & 0.01 \\
\hline & $\begin{array}{l}1.19 \\
0.16\end{array}$ & $\begin{array}{l}0.17 \\
0.30\end{array}$ & $\begin{array}{l}0.97 \\
0.18\end{array}$ & $\begin{array}{l}0.30 \\
0.00\end{array}$ & $\begin{array}{l}0.20 \\
0.85\end{array}$ & $\begin{array}{l}1.33 \\
3.05\end{array}$ & $\begin{array}{l}0.72 \\
0.23\end{array}$ & $\begin{array}{l}0.00 \\
0.00\end{array}$ & $\begin{array}{l}0.000 \\
0.21\end{array}$ & $\begin{array}{l}0.000 \\
0.47\end{array}$ & $\begin{array}{l}0.15 \\
0.24\end{array}$ & $\begin{array}{l}0.16 \\
0.57\end{array}$ & $\begin{array}{l}4.58 \\
0.13\end{array}$ & $\begin{array}{l}0.87 \\
8.56\end{array}$ & $\begin{array}{l}0.88 \\
0.30\end{array}$ & $\begin{array}{l}4.41 \\
0.92\end{array}$ & $\begin{array}{l}2.15 \\
0.26\end{array}$ & $\begin{array}{l}.023 \\
0.09\end{array}$ & $\begin{array}{l}2.32 \\
1.55\end{array}$ \\
\hline $\begin{array}{l}\mathrm{La} \\
\mathrm{Ce}\end{array}$ & $\begin{array}{l}0.16 \\
0.33\end{array}$ & $\begin{array}{l}0.50 \\
0.72\end{array}$ & $\begin{array}{l}0.18 \\
0.05\end{array}$ & $\begin{array}{l}0.00 \\
0.00\end{array}$ & $\begin{array}{l}0.85 \\
2.69\end{array}$ & $\begin{array}{l}3.05 \\
10.48\end{array}$ & $\begin{array}{l}0.23 \\
0.74\end{array}$ & $\begin{array}{l}0.00 \\
0.02\end{array}$ & $\begin{array}{l}.211 \\
1.06\end{array}$ & $\begin{array}{l}\text {. } 1.71 \\
1.72\end{array}$ & $\begin{array}{l}0.24 \\
0.90\end{array}$ & $\begin{array}{l}.0 .31 \\
2.33\end{array}$ & $\begin{array}{l}.113 \\
0.29\end{array}$ & $\begin{array}{l}\text {. } 3.56 \\
30.19\end{array}$ & $\begin{array}{l}\text {. } 1.30 \\
1.32\end{array}$ & $\begin{array}{l}.922 \\
3.29\end{array}$ & $\begin{array}{l}0.86 \\
0.84\end{array}$ & $\begin{array}{l}0.09 \\
0.28\end{array}$ & $\begin{array}{l}1.53 \\
5.82\end{array}$ \\
\hline Nd & 0.40 & 1.05 & 0.22 & 0.01 & 3.81 & $\begin{array}{l}0.26 \\
9.26\end{array}$ & 0.60 & 0.03 & 1.56 & 1.23 & 0.75 & 2.20 & 0.49 & 16.89 & 0.61 & 3.21 & $\begin{array}{l}1.15 \\
1.15\end{array}$ & 0.15 & 6.44 \\
\hline $\mathrm{Sm}$ & 0.17 & 0.54 & 0.05 & 0.00 & 1.92 & 3.33 & 0.17 & 0.01 & 0.68 & 0.34 & 0.22 & 0.72 & 0.15 & 4.43 & 0.16 & 1.28 & 0.58 & 0.04 & 2.53 \\
\hline Eu & 0.10 & 0.41 & 0.05 & 0.02 & 0.24 & 0.96 & 0.11 & 0.01 & 0.26 & 0.10 & 0.06 & 0.19 & 0.07 & 0.52 & 0.25 & 0.63 & 0.45 & 0.04 & \\
\hline$\underset{\mathrm{U}}{\mathbf{G d}}$ & $\begin{array}{l}0.33 \\
5.05\end{array}$ & $\begin{array}{l}0.80 \\
0.01\end{array}$ & $\begin{array}{l}0.08 \\
3.27\end{array}$ & $\begin{array}{l}0.00 \\
1.52\end{array}$ & $\begin{array}{l}2.57 \\
0.02\end{array}$ & $\begin{array}{l}4.09 \\
0.06\end{array}$ & $\begin{array}{l}0.23 \\
2.22\end{array}$ & $\begin{array}{l}0.00 \\
4.50\end{array}$ & $\begin{array}{l}0.89 \\
0.02\end{array}$ & $\begin{array}{l}0.40 \\
0.16\end{array}$ & $\begin{array}{l}0.24 \\
0.03\end{array}$ & $\begin{array}{l}0.85 \\
1.19\end{array}$ & $\begin{array}{l}0.20 \\
198\end{array}$ & $\begin{array}{l}4.86 \\
009\end{array}$ & $\begin{array}{l}0.17 \\
0.47\end{array}$ & $\begin{array}{l}1.72 \\
0.04\end{array}$ & $\begin{array}{l}0.86 \\
0.01\end{array}$ & $\begin{array}{l}0.05 \\
0.06\end{array}$ & $\begin{array}{l}3.23 \\
0.02\end{array}$ \\
\hline 0 & 5.05 & 0.01 & 3.27 & 1.52 & 0.02 & 0.06 & 2.22 & & 0.02 & & 0.03 & 1.19 & & & 0.47 & & & & 0.02 \\
\hline
\end{tabular}

Notes:

Depths are given as meters below surface (mbsf).

Abbreviations: LOI = Loss on Ignition; Serpentinized: Serp; Metagb: metagabbro; Metasom: metasomatic overprinting

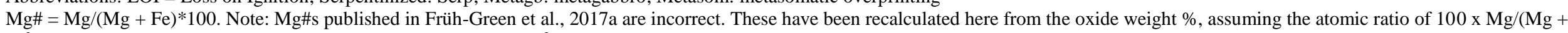
$\mathrm{Fe}^{2+}$ ), using molecular weights and a factor of 0.8998 to calculate $\mathrm{Fe}^{2+}$ from $\mathrm{Fe}_{2} \mathrm{O}_{3}$. 

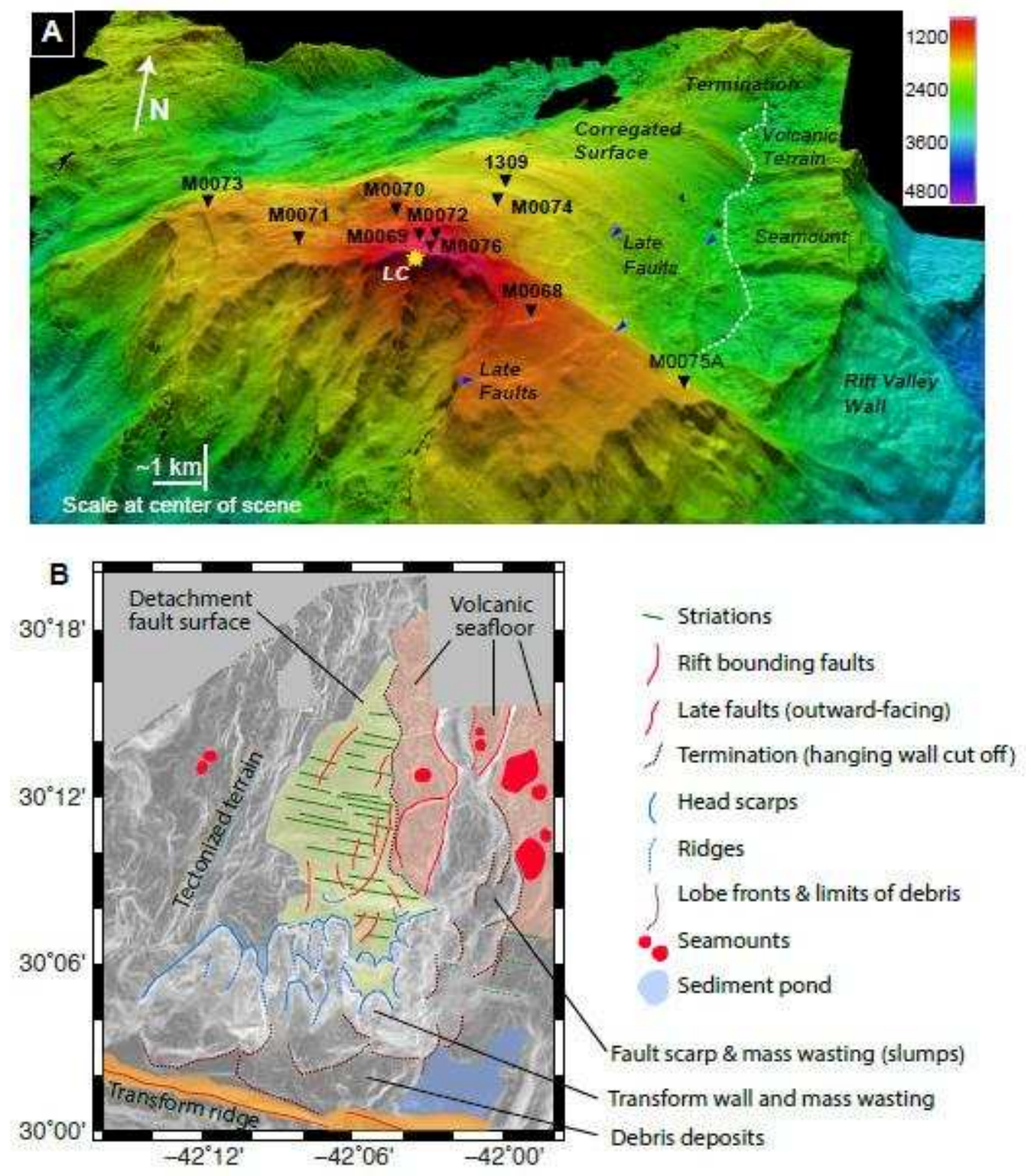

Figure 1. Bathymetry together with structural and morphological characteristics of the Atlantis Massif. (a) 3-D terrain model with a northward view of the detachment fault surface showing striations associated with detachment faulting, cross-cutting tectonic structures, with locations of the IODP Expedition 357 drill sites, the Lost City hydrothermal field (LC, yellow star) and IODP Site U1309. Based on new multibeam bathymetry acquired at $50 \mathrm{~m}$ resolution. (b) Interpretation of structural and morphological characteristics from new bathymetry data acquired during the expedition (reproduced from Früh-Green et al., 2017a). 

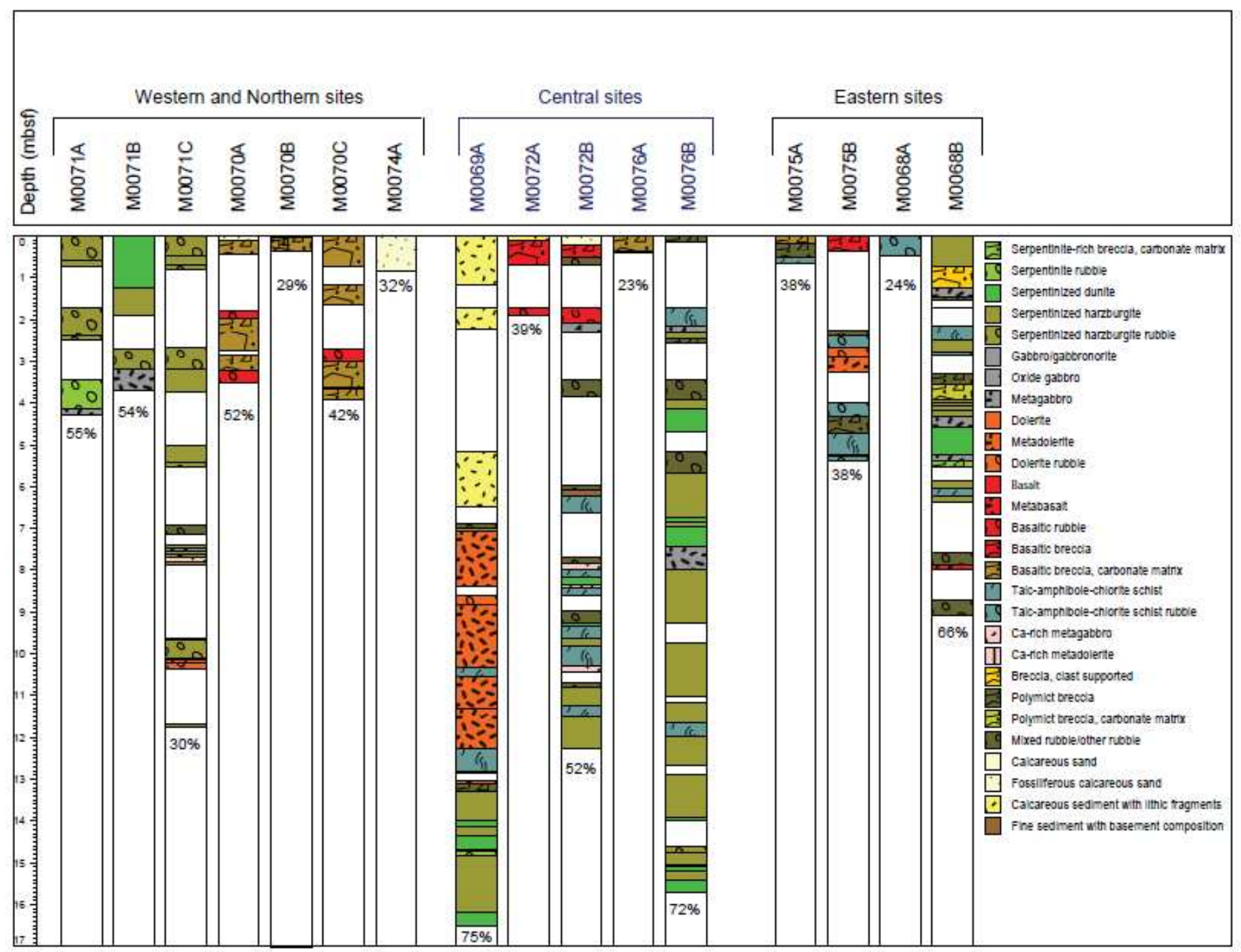

Figure 2. Lithologic variations on a regional scale and with depth in cores recovered during IODP Expedition 357. Percentages indicate overall percent core recovery for each hole. The central sites, highlighted in blue, recovered in situ sequences, whereas talus debris was recovered at the western and eastern sites along the southern ridge. 
a) M0071A-1R1

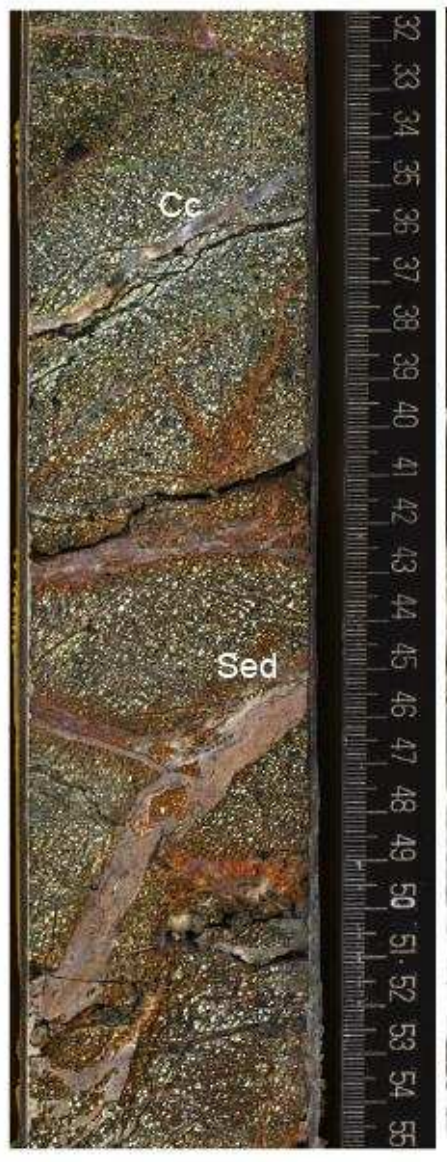

b) M0076B-6R1

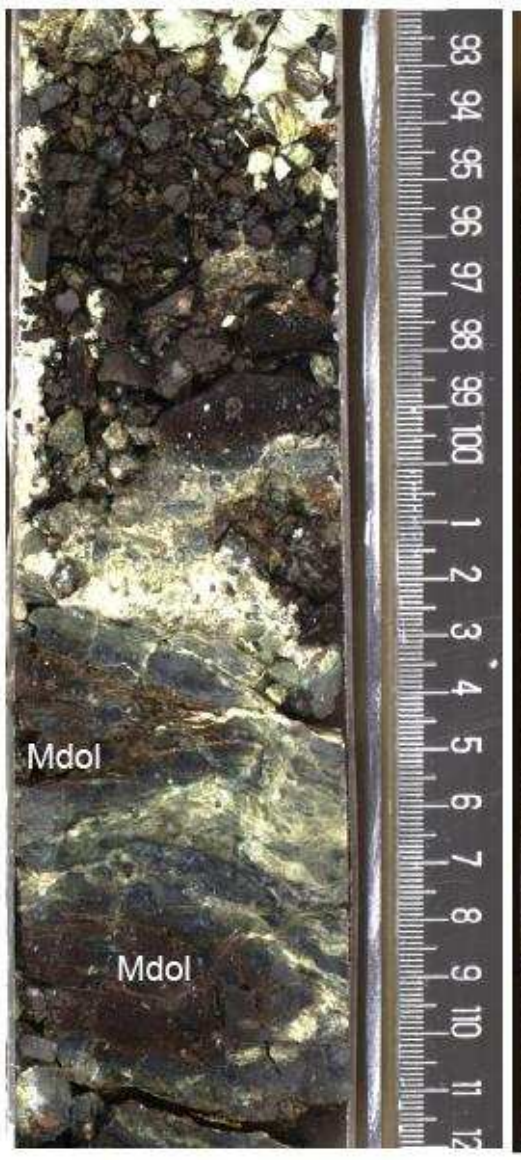

c) M0076B-7R1

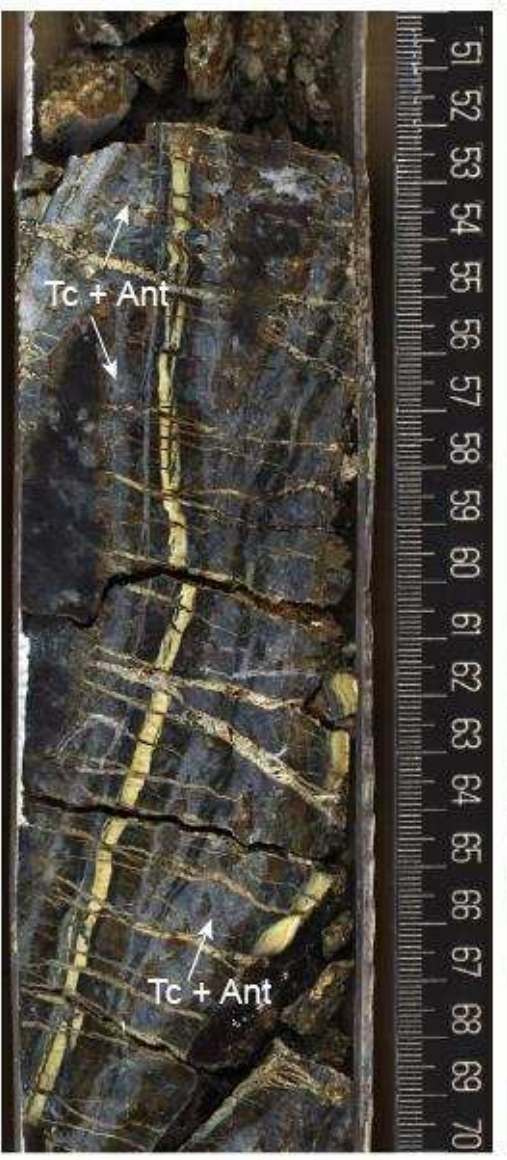

d) M0072B-6R1

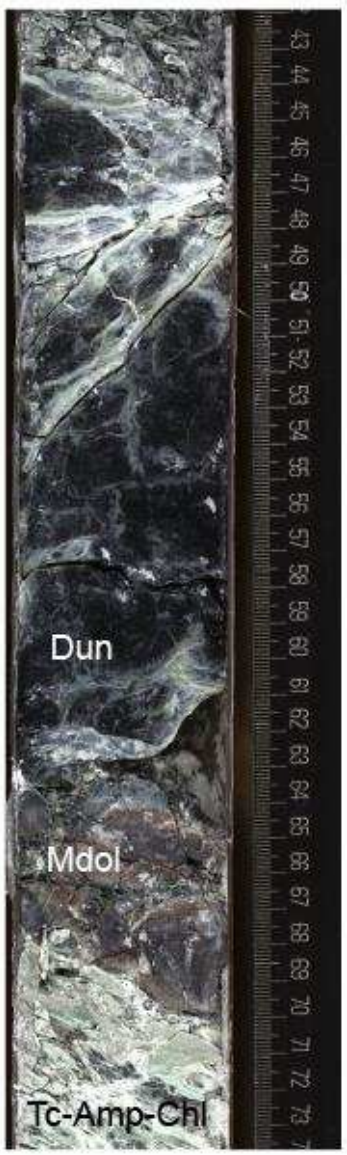

Figure 3. Examples of variations in rock type and structures in IODP Exp. 357 drill cores. (a) Serpentinized and oxidized dunite cut by moderately dipping calcite veins $(\mathrm{Cc})$ and fractures filled with foraminiferous carbonate sediment (Sed). (b) Relationships between schistose zone talc-amphibole-chlorite schists (greenish-white domains) at the contact to cataclastically deformed metadolerite (Mdol). (c) Steeply dipping banded serpentine \pm talc veins cutting serpentinized harzburgite. Light grey domains are previous fluid pathways resulting in metasomatic replacement of antigorite (Ant) by talc (Tc) (Rouméjon et al., 2018). (d) Metasomatic zones of talc-amphibole-chlorite schist (Tc-Amp-Chl) at contact to serpentinized dunite (Dun) intruded by dolerite and transitioning again to talc-amphibole-chlorite schist. Photos: IODP ESO. 

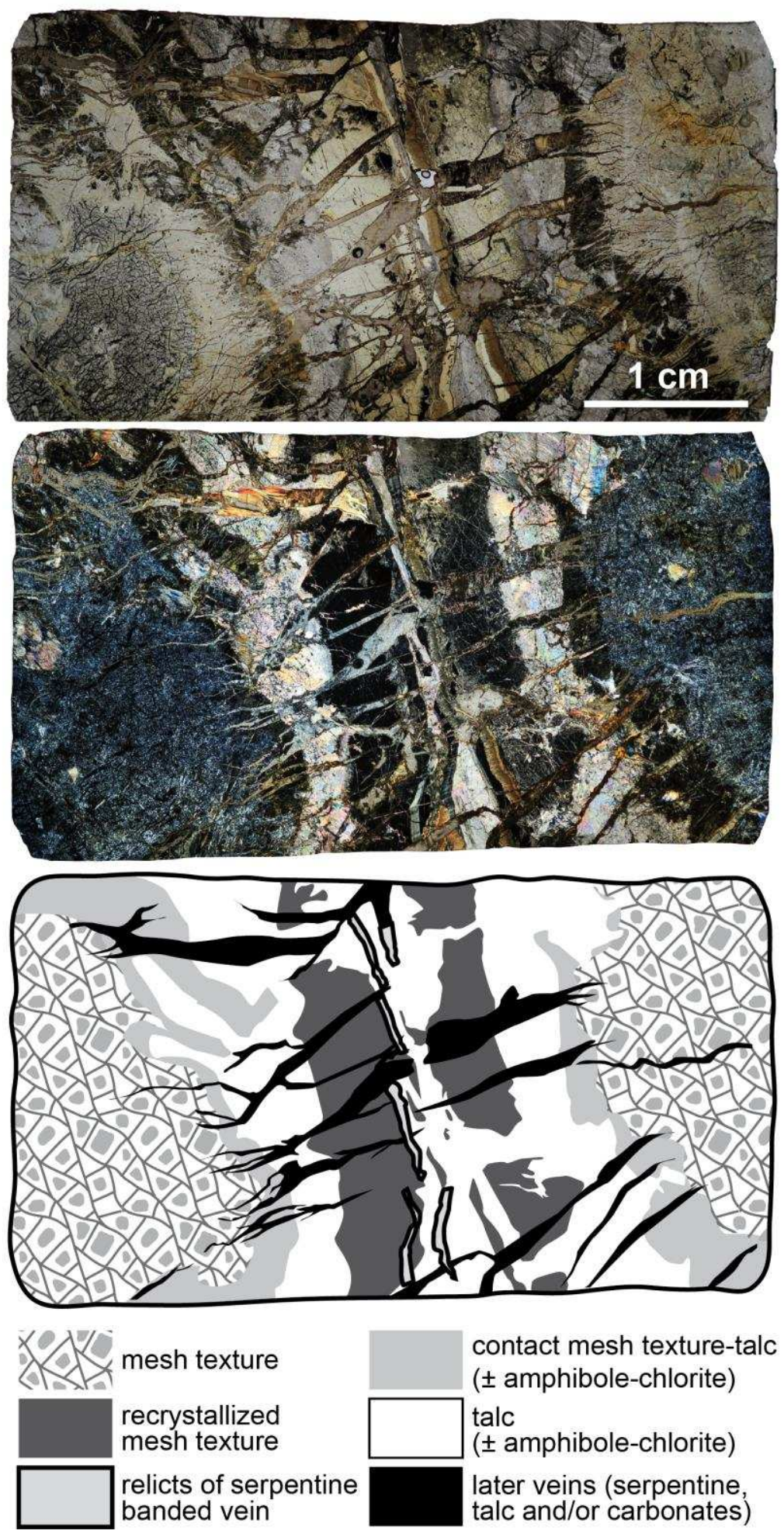

Figure 4. Characteristic serpentine textures and cross-cutting relationships associated with progressive alteration and veining in serpentinized harburzgite (example from M0076B-7R1, 43-45cm); (a) plane polarized light, (b) crossed polarized light, and (c) schematic representation of overprinting relationships. Modified from Früh-Green et al., 2017d, Fig. 7. 
Figure 5

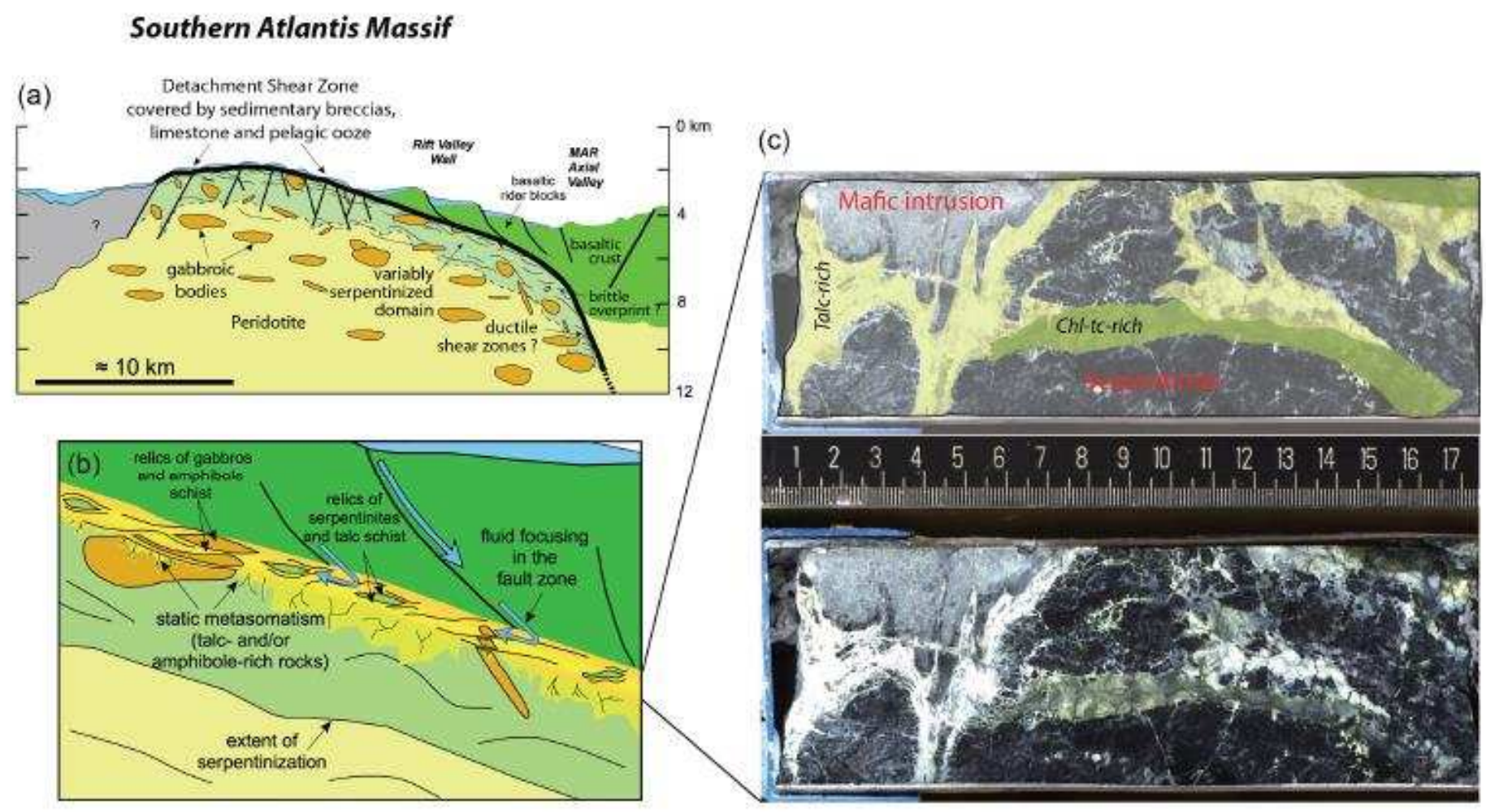

Figure 5. Model of the tectono-magmatic evolution and alteration of heterogeneous lithosphere at Atlantis Massif. (a) Interpretative cross section showing fluid pathways, metasomatic zones and extent of serpentinization (light green shaded region) related to detachment faulting and steep normal faults (modified after Boschi et al., 2006a). (b) Detail of <100 m detachment shear zone (in red-yellow) characterized by heterogeneous, variably altered and deformed gabbroic and peridotite lithologies and with extensive synkinematic metasomatism. The resulting talc-amphibole schists enclose lenses of relic, locally less deformed, serpentinite and gabbroic rocks (modified from Boschi et al., 2006a). (c) Example of magmatic intrusion in a fully serpentinized harzburgite from Core M0072-8R2, 0-18 cm. Late metasomatic alteration at the contact between the mafic/ultramafic rocks produced white and green talc-amphibole-chlorite assemblages that crosscut the previous texture. $\mathrm{Chl}=$ chlorite, $\mathrm{tc}=$ talc (reproduced from Früh-Green et al., 2017d, Fig. 13). 


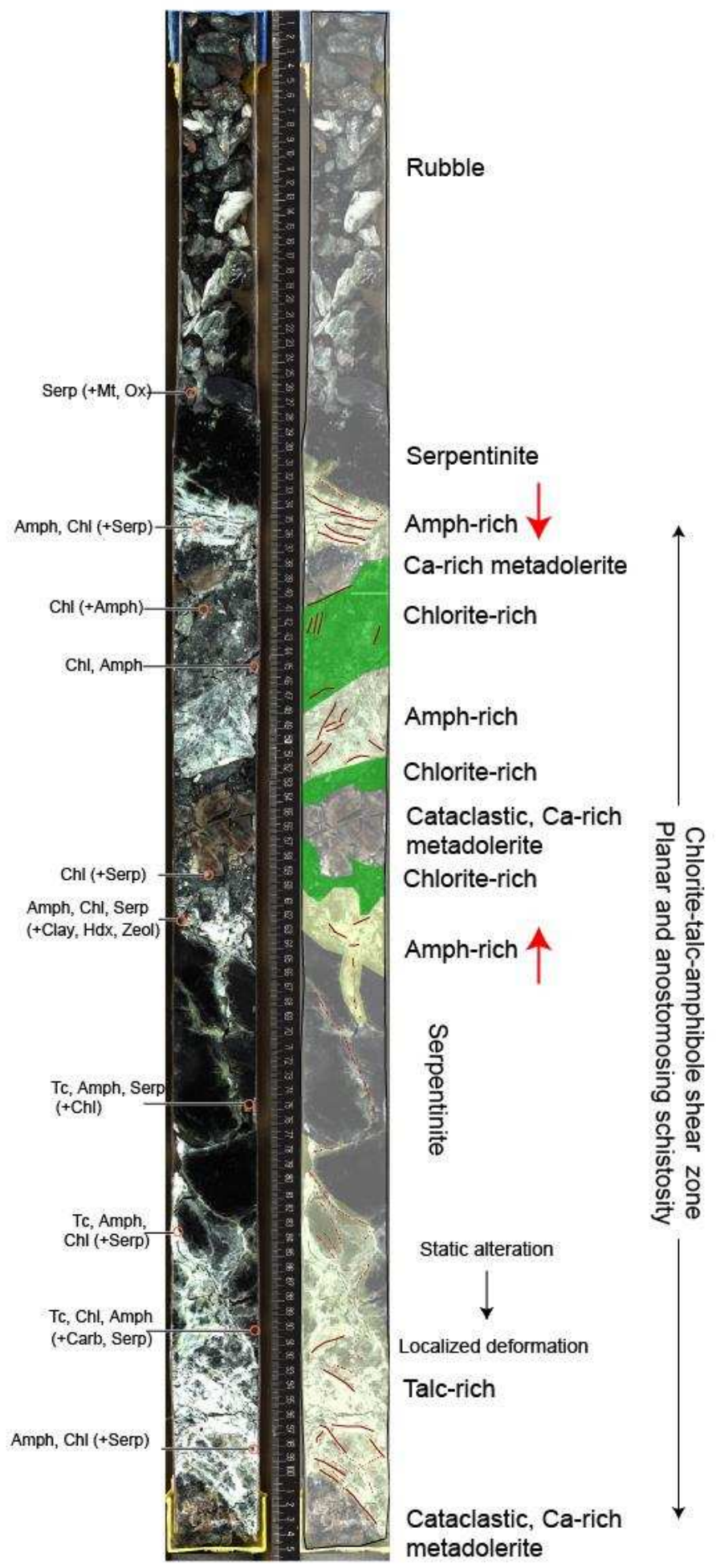

Figure 6. Example of complex lithological and deformation relationships between mafic intrusions in peridotite and metasomatic domains in the IODP Expedition 357 cores, showing a transition from static alteration to strain localization in alternating talc-, amphibole-, and chlorite-rich shear zones (from Core M0072B-7R-1, 0-105 $\mathrm{cm})$. Red circles $=$ samples taken for XRD analyses and corresponding mineral assemblages. Serp $=$ serpentinite, $\mathrm{Mt}=$ magnetite, $\mathrm{Ox}=$ oxide, $\mathrm{Amph}=$ amphibole, $\mathrm{Chl}=$ chlorite, $\mathrm{Hdx}=$ hydroxide, Zeol = zeolite, Carb $=$ carbonate. Modified from Früh-Green et al., 2017d, Fig. 12. 


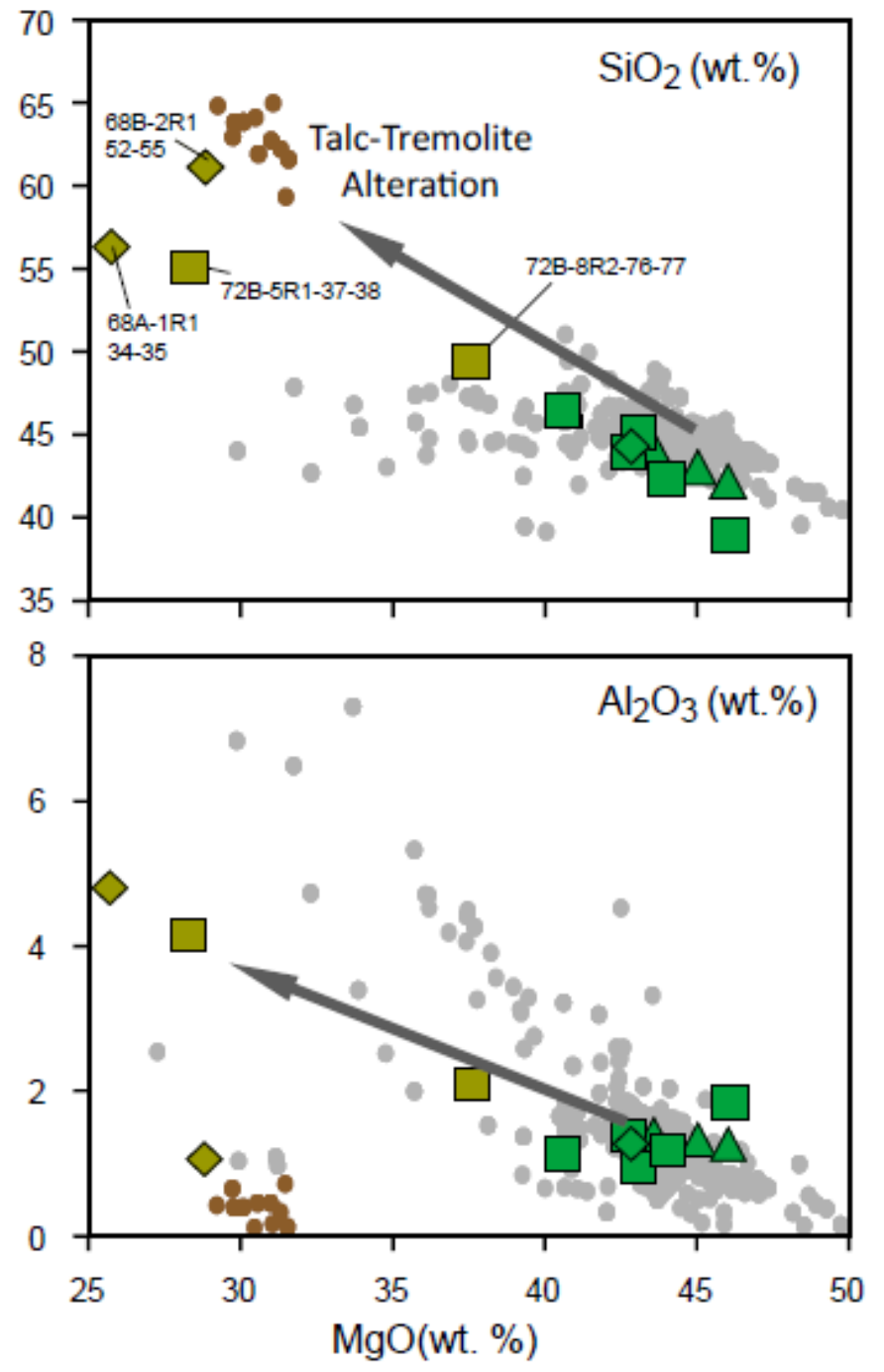

Western Sites

$\Delta$ utramafic rocks

$\Delta$ talc-amphibole-chlorite schists $\square$ talc-amphibole-chlorite schists
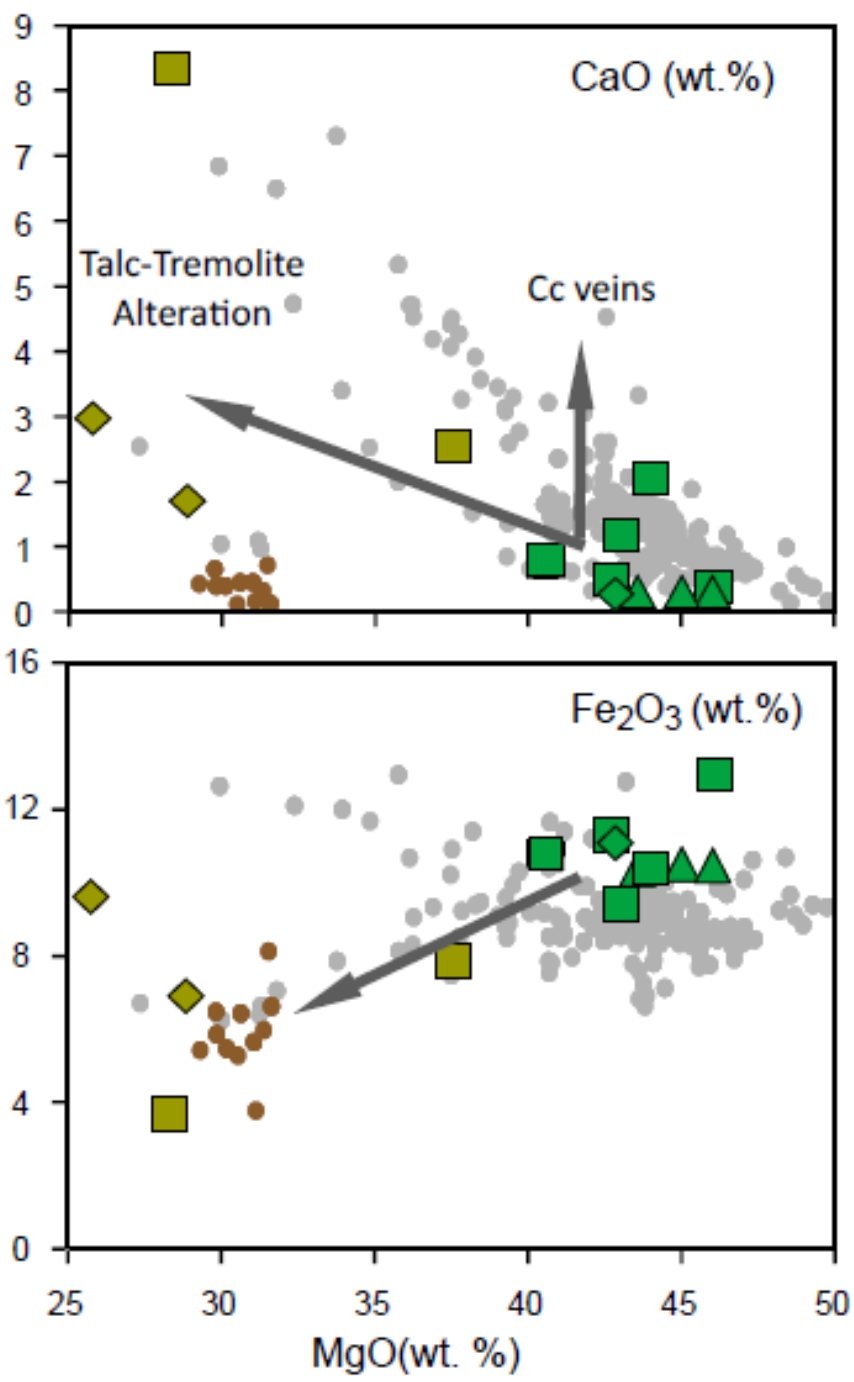

Eastern Sites

$\diamond$ ultramafic rocks

$\diamond$ talc-amphibole-chlorite schists

\section{Mid-Atlantic Ridge abyssal peridotites}

ODP 209, Hole 1268A talc-altered peridotites

Figure 7. Selected whole-rock major elements (normalized, volatile-free compositions, and in weight $\%$ oxides, wt \%) vs. MgO for serpentinized ultramafic rocks (including impregnated / metasomatized samples) and talcamphibole-chlorite schists from Atlantis Massif, IODP Exp. 357. Data from Mid-Atlantic-Ridge abyssal serpentinized peridotites and talc-altered peridotites are shown for comparison. Talc-amphibole alteration is associated with a general trend to higher $\mathrm{Si}, \mathrm{Ca}$ and $\mathrm{Al}$ compositions and a decrease in $\mathrm{Mg}$ and $\mathrm{Fe}$. Global abyssal peridotite field defined by data from PetDB (http://www.earthchem.org/petdb, May 2016). Data for talc-altered peridotite field from ODP Leg 209, Hole 1268A (Paulick et al., 2006; also from PetDB). Modified from Früh-Green et al., 2017a, Fig. 11. 


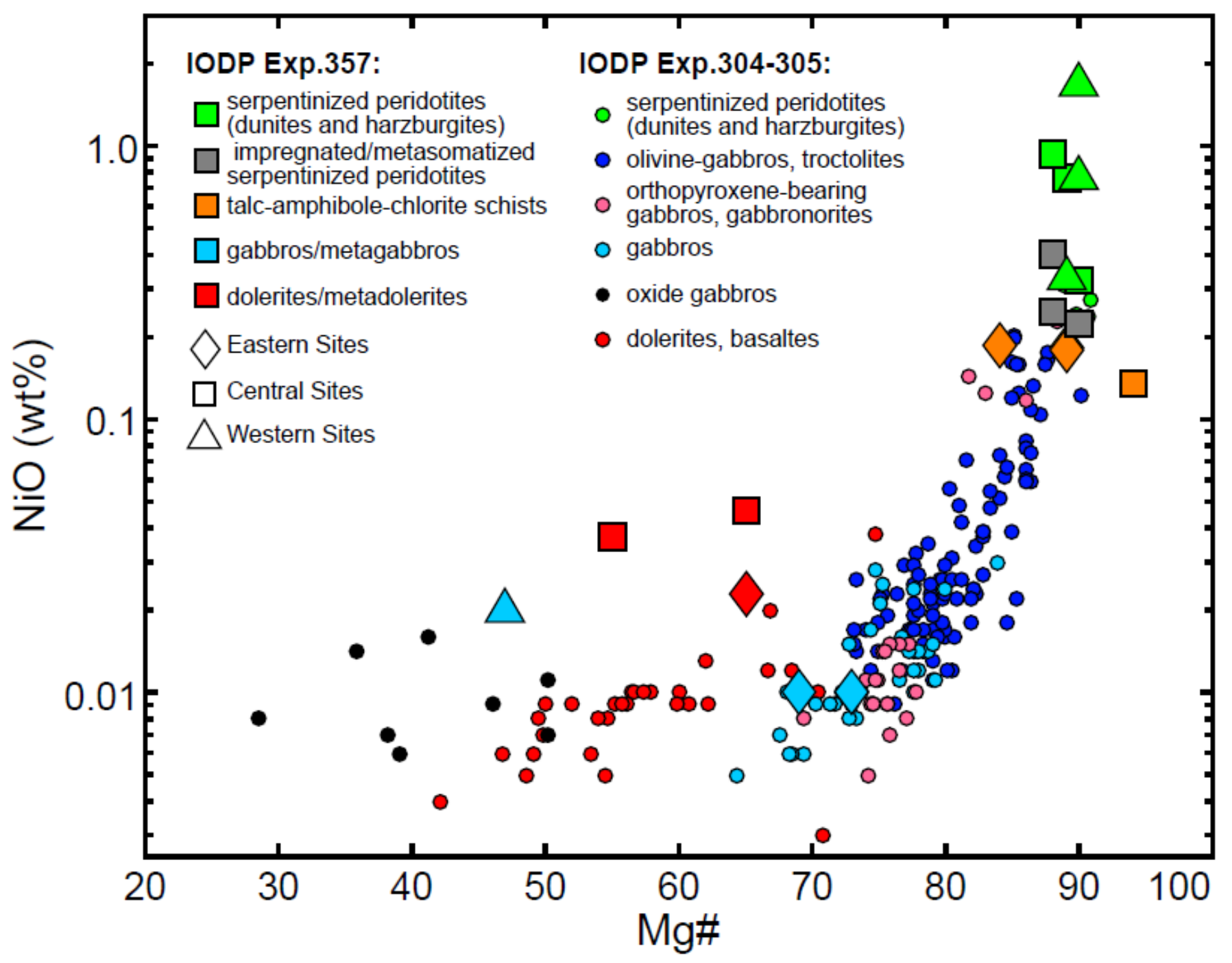

Figure 8. Ni concentrations (calculated as weight \% (wt \%) oxides and normalized to volatile-free concentrations, plotted on a log scale) vs. Mg\# of Atlantis Massif mafic and ultramafic rocks from Expedition 357 compared with those from cores recovered at Site U1309 during Integrated Ocean Drilling Program Expedition 304/305 (Godard et al., 2009). 

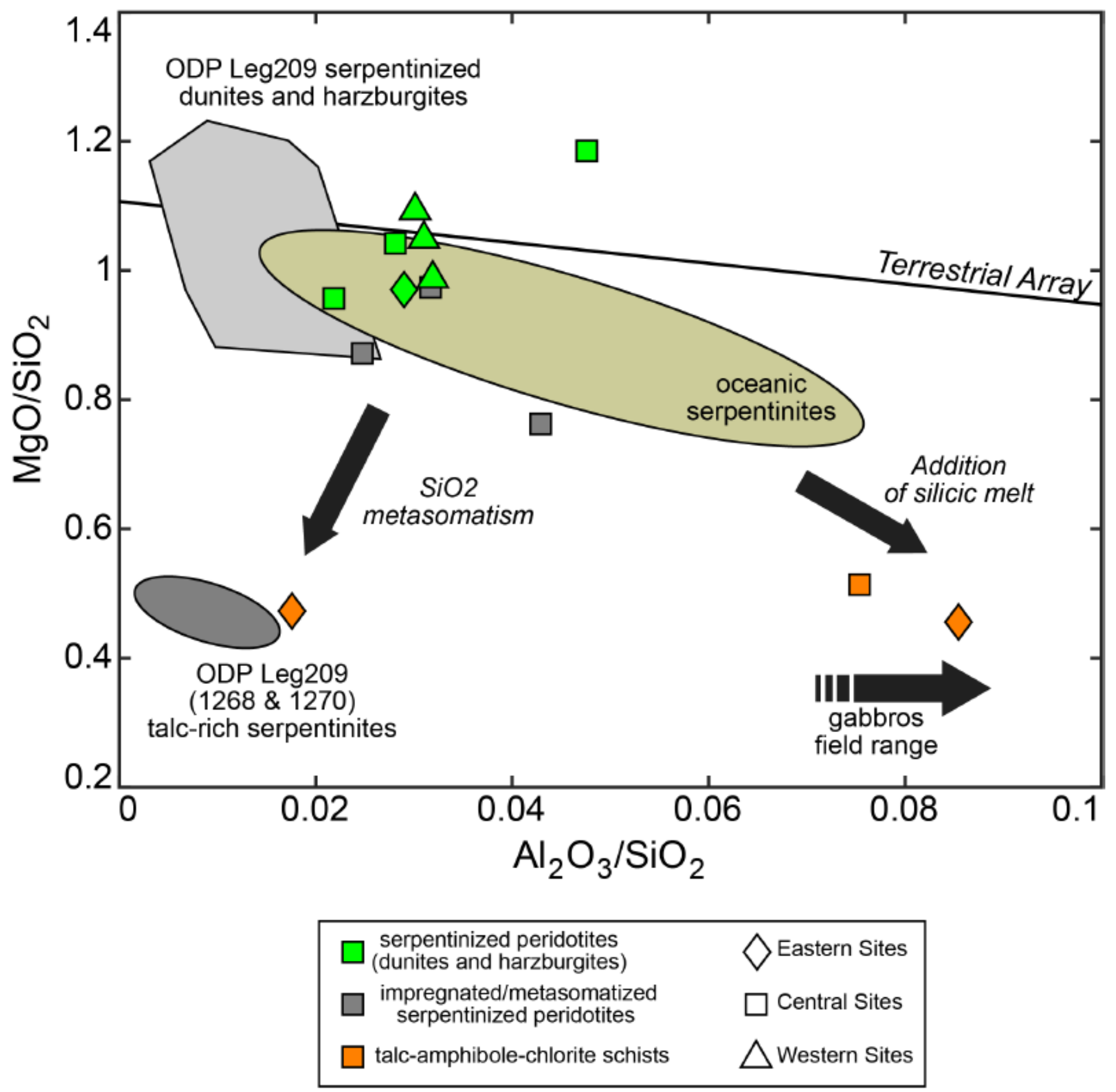

Figure 9. $\mathrm{MgO} / \mathrm{SiO}_{2}$ vs $\mathrm{Al}_{2} \mathrm{O}_{3} / \mathrm{SiO}_{2}$ diagram showing variations in bulk rock chemistry and changes with $\mathrm{Si}$ metasomatism. Atlantis Massif compositions are also compared with compositions of serpentinites and talc schists from IODP Site U1309 and from 15²0'N recovered during ODP Leg 209 (Paulick et al., 2006) as well as the global data set of abyssal peridotites reported in Niu (2004), which define a trend parallel to the terrestrial array (Jagoutz et al., 1979). The geochemistry of the Atlantis Massif samples reflects a variety of processes including modal mineralogical composition, melt impregation and multiple phases of hydrothermal alteration. 


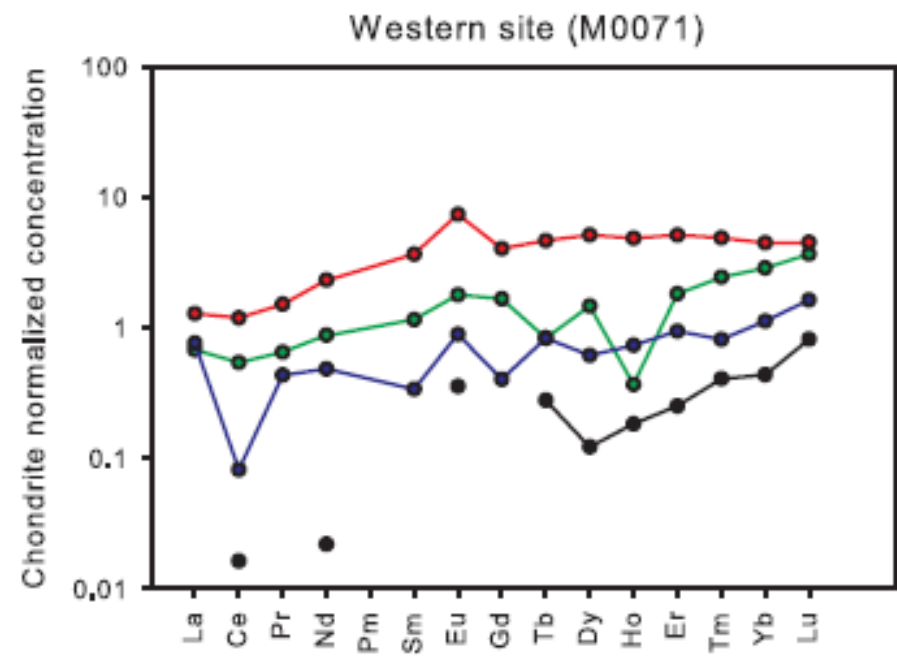

Metagabbro (Blackwall)

$\rightarrow$ M0071A-2R1-64-67cm

Serpentinized Harzburgite

$\rightarrow$ M0071C-1R1-11-13cm

$\rightarrow$ M0071C-2R1-74-76cm

Serpentinized Dunite

$\rightarrow$ M0071A-1R2-120-121cm

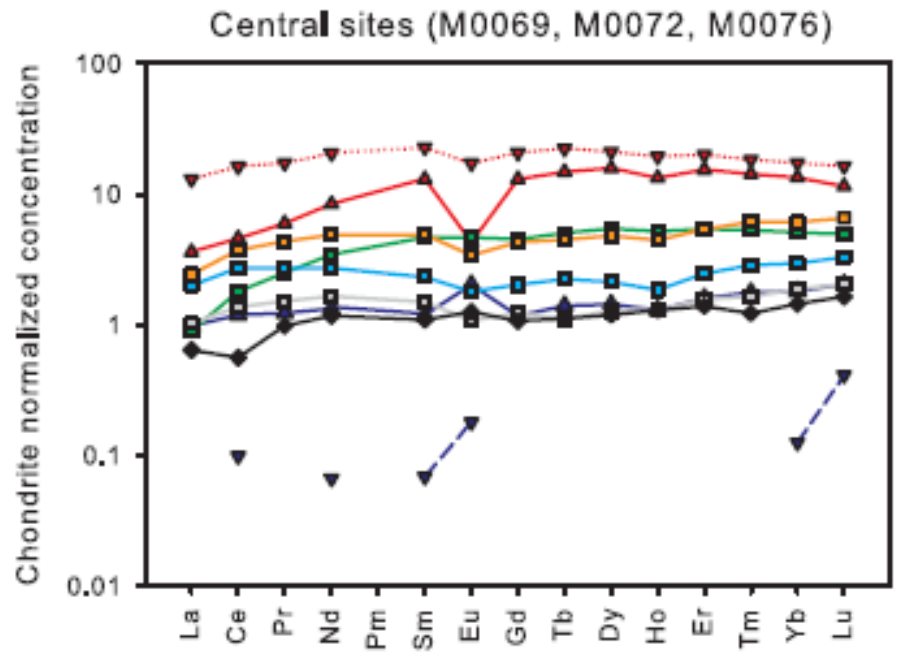

Metadolorites

$\longrightarrow$ M0069A-5R1-29.5-32cm

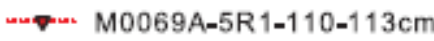

Talc-amphibole-chlorite Schist

$\rightarrow-M 0072 B-5 R 1-37-38 \mathrm{~cm}$

Metasomatised Harzburgite

- - M0072B-7R1-72.5-75cm

- M0072B-8R 1-34-38cm

- M0072B-8R2-76-77cm

Serpentinized Harzburgite

- M0069A-10R1-80-87cm

$\longrightarrow$ M0076B-7R1-81-83cm

Serpentinized Dunite

$\longrightarrow-$ M0069A-10R3-0-2.5cm

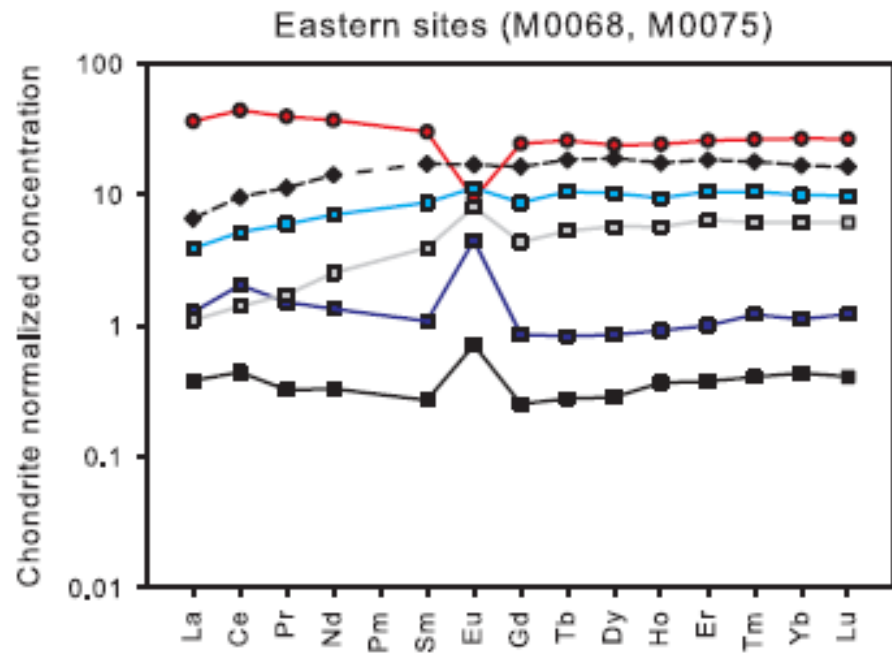

Metadolorites

$\rightarrow-M 0075 B-2 R 1-66-68 \mathrm{~cm}$

Gabbro / Metagabbro

-a- M0068B-1R1-134-139cm

- M0068B-2R1-31-36cm

Talc-amphibole-chlorite Schist

$\rightarrow-M 0068$ A-1R1-34-35cm

- - M0068B-2R1-52-55cm

Serpentinized Harzburgite

- M0068B-1R1-37.5-40cm

Figure 10. Compilation of chondrite-normalized REE concentrations of Atlantis Massif mafic and ultramafic rocks from samples of the IODP Expedtion 357 drill cores (see Table 2). Values for CI chondrite from McDonough and Sun, 1995. 

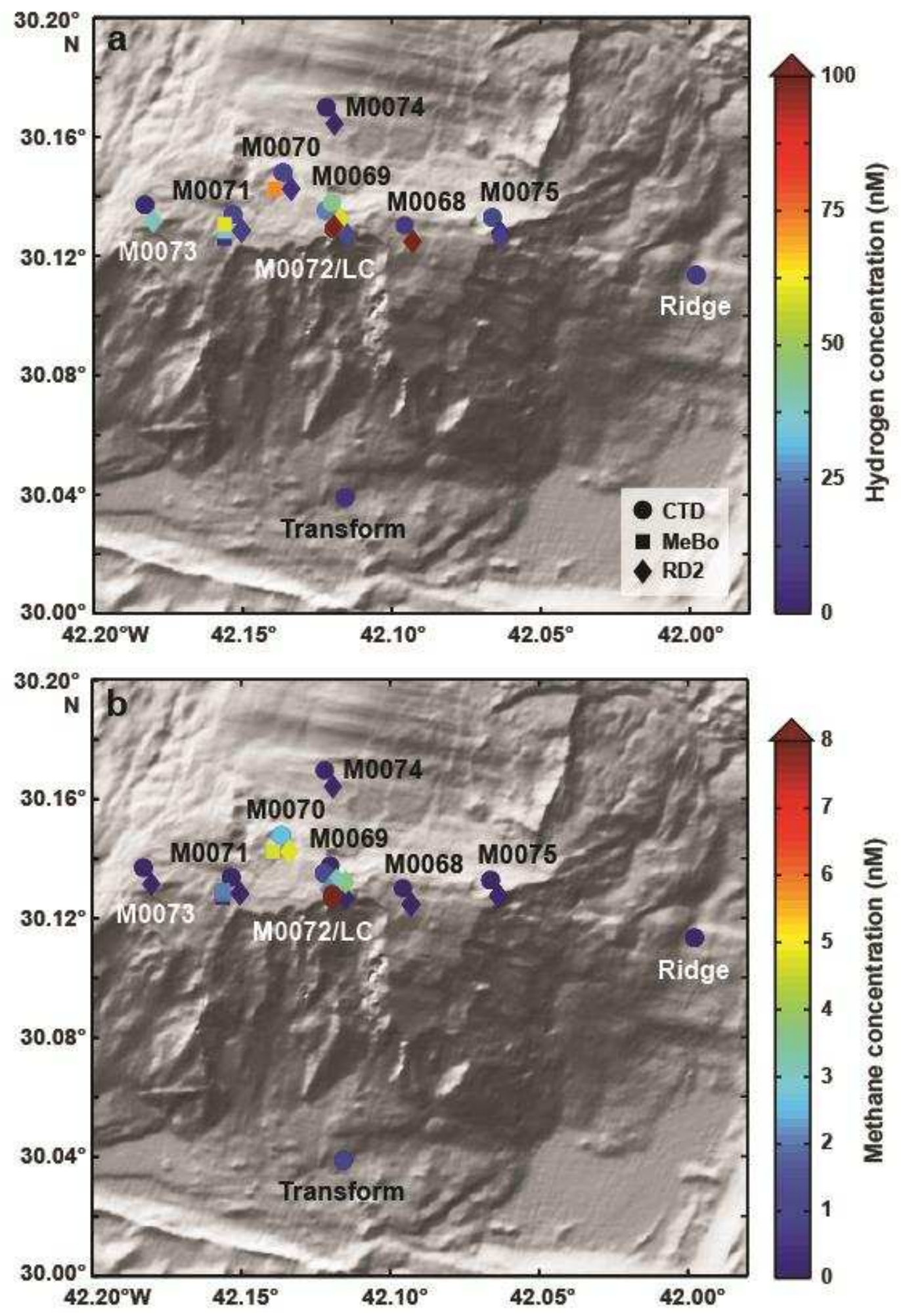

Figure 11. Highest measured hydrogen and methane concentrations in samples from CTD rosette bottom waters acquired before drilling and sensor package Niskin bottles taken by RD2 and MeBo after drilling at the Atlantis Massif drill sites during IODP Expedition 357. Dark red circles indicate samples from the Lost City (LC) plume. 


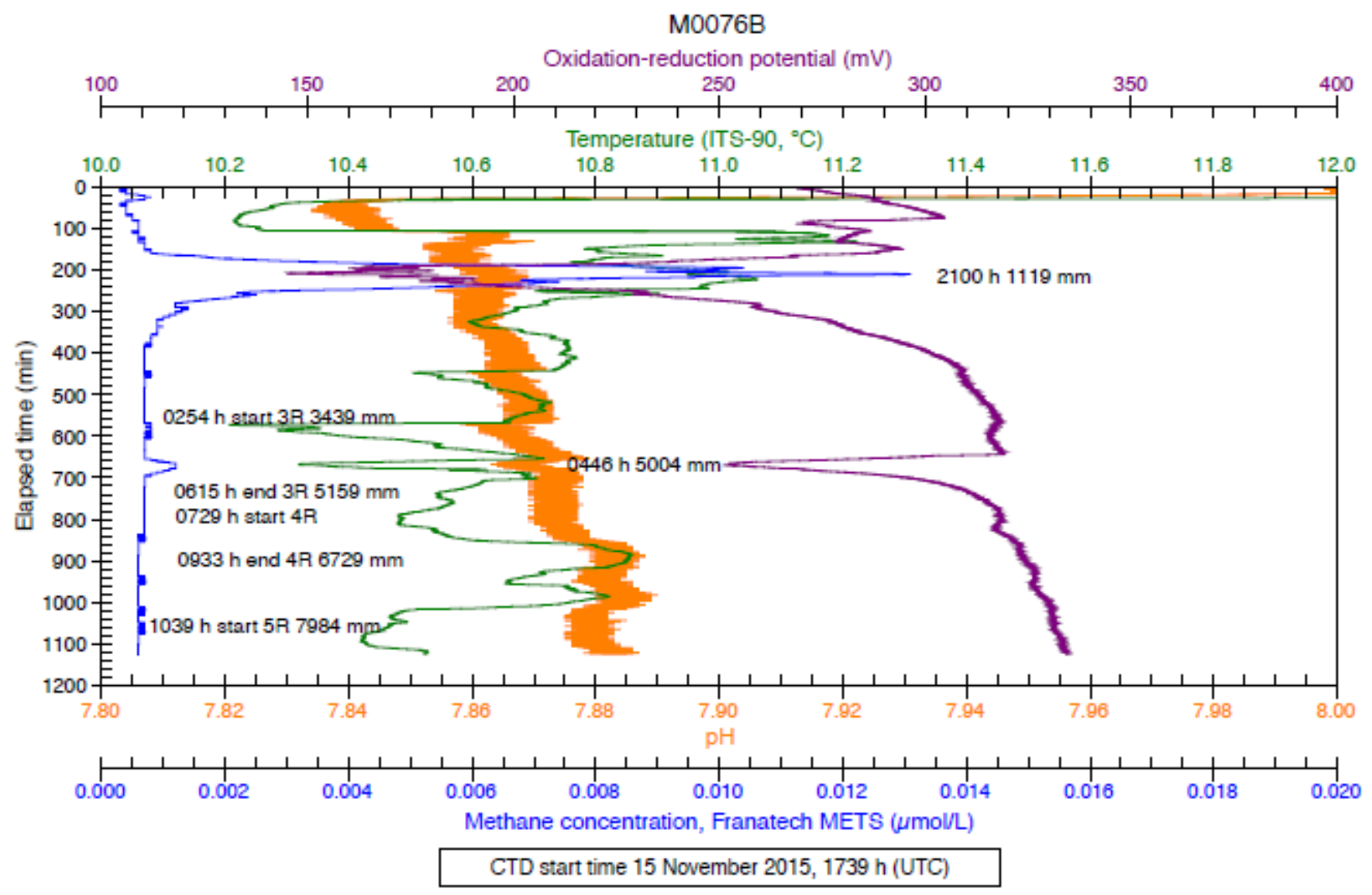

Figure 12. Example of variations in fluid chemistry during drilling operations and correlations of geochemical signatures recorded by the sensor packages on the rock drills from sensor data for Hole M0076B, Cores 1R-5R. Elapsed time $=$ time since the start of the sensor package data file. Penetration depth (in $\mathrm{mm}$ ) was reconstructed from drill logs. 


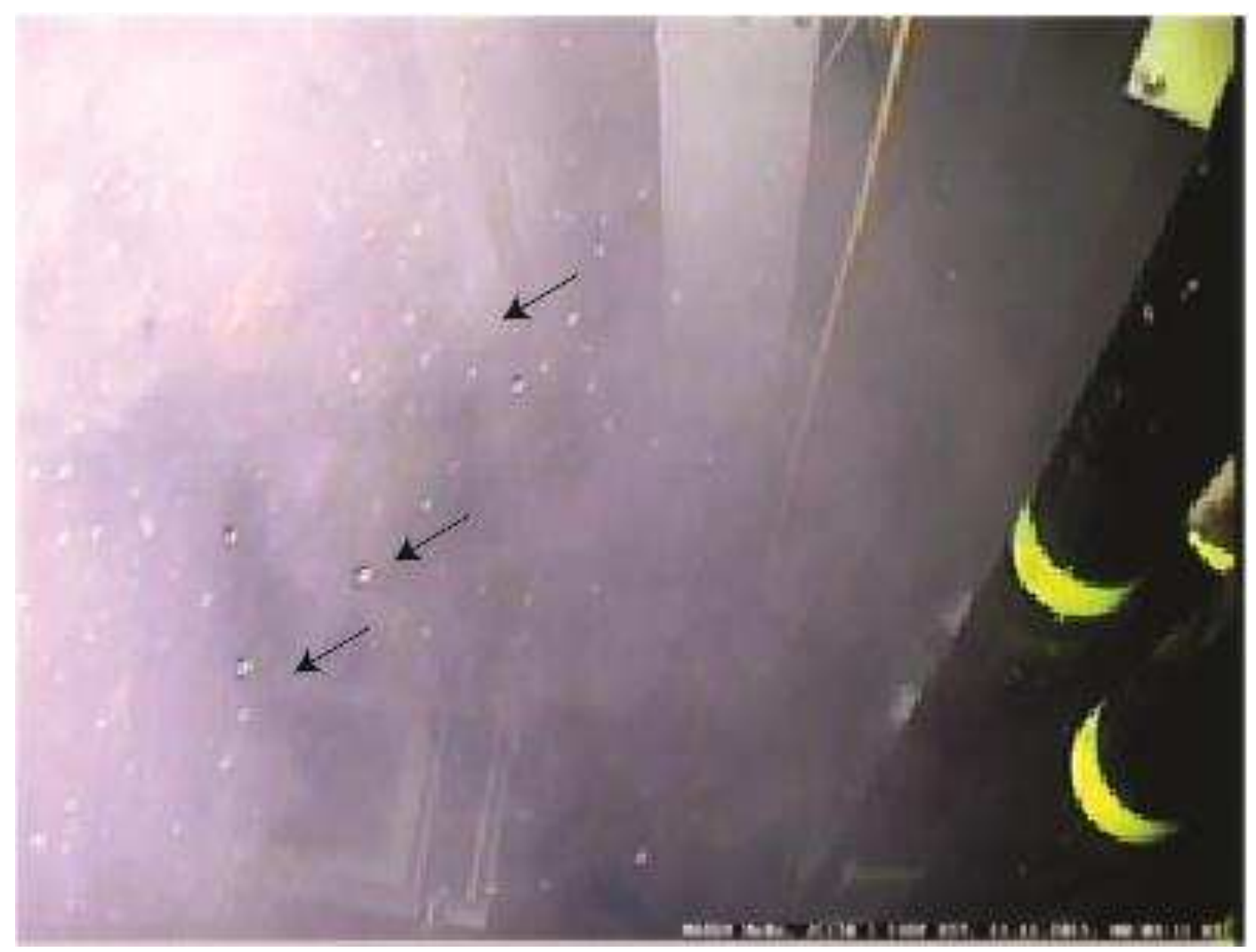

Figure 13. Frame-grab photograph from drilling video of bubbles (black arrows) that were observed issuing from Hole M0070C and around the drill base during operations at this site, even when coring had stopped. 


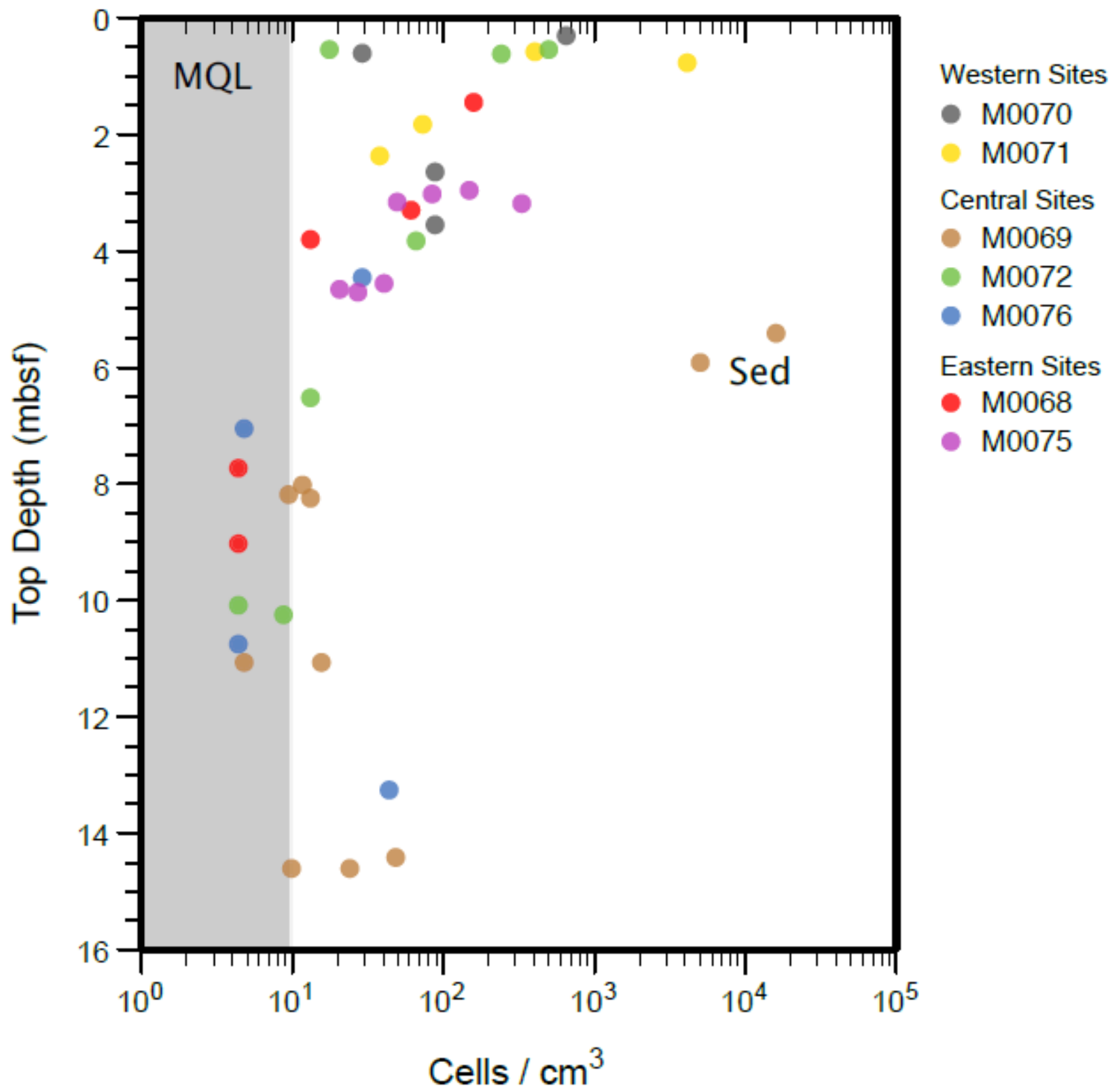

Figure 14. Downhole variations in cell counts from interior portions of whole round cores of the basement rock samples (and two sediment (Sed) samples from Hole M0069A) taken onboard during IODP Exp. 357. Data from Hole M0074 not included due to extensive damage to this short sediment core. The shaded region shows the range of counts below the minimum quantification limit (MQL) of 9.8 cells cm$~^{-3}$. 